ISSN 1996-1944

www.mdpi.com/journal/materials

Review

\title{
A Comprehensive Review on Separation Methods and Techniques for Single-Walled Carbon Nanotubes
}

\author{
Naoki Komatsu * and Feng Wang \\ Department of Chemistry, Shiga University of Medical Science, Seta, Otsu, Shiga 520-2192, Japan; \\ E-Mail: psfwang@ belle.shiga-med.ac.jp (F.W.) \\ * Author to whom correspondence should be addressed; E-Mail: nkomatsu@ belle.shiga-med.ac.jp; \\ Tel.: +81-77-548-2102; Fax: +81-77-548-2405.
}

Received: 11 May 2010; in revised form: 22 June 2010 / Accepted: 25 June 2010 /

Published: 30 June 2010

\begin{abstract}
Structural control of single-walled carbon nanotubes (SWNTs) is attracting enormous interest in view of their applications to nanoelectronics and nanooptics. Actually, more than 200 papers regarding separation of SWNTs have been published since 1998. In this review, they are classified into the following five sections according to the separation methods; electrophoresis, centrifugation, chromatography, selective solubilization and selective reaction. In each method, all literature is summarized in tables showing the separated objects (metallic/semiconducting (M/S), length, diameter, $(n, m)$ structure and/or handedness), the production process of the used SWNTs (CoMoCAT, HiPco, arc discharge and/or laser vaporization) and the employed chemicals, such as detergents and polymers. Changes in annual number of publications related to this subject are also discussed.
\end{abstract}

Keywords: carbon nanotubes; separation

\section{Introduction}

Structural control of single-walled carbon nanotubes (SWNTs) is attracting enormous interest because the physical properties are closely correlated to their structures and the application frequently requires homogeneous properties. In this context, extensive investigations have been made in pursuit of selective synthesis and separation of SWNTs with specific structural properties. As for the 
synthesis, limited $(n, m)$ structures of SWNTs were synthesized using a silica-supported Co-Mo catalyst [1,2] and the catalyst system of Co-incorporated mobile composition of matter 41 (Co-MCM-41) [3,4]. Great progress has been made quite recently on the synthesis using non-metal catalysts [5-9], and selective synthesis of metallic and semiconducting SWNTs [10,11].

On the other hand, separation of SWNTs is an alternative way to obtain SWNTs with specific electrical and structural properties, and a wide variety of methods have been devised so far for the separation according to metallic and semiconducting (M/S) property, diameter, length, roll-up index $((n, m)$ structure) and handedness ( $M$ or $P$ structure defined in Figures 2 and 3$)$. Herein, papers related with CNT separation are categorized and tabulated according to the five methods based on electrophoresis, centrifugation, chromatography, selective solubilization and selective reaction. As for solubilization of carbon nanotubes (CNTs), there have been a number of reviews [12-17]. Several excellent reviews have also been published on separation of CNTs [18-24]. Therefore, the authors mainly focus on the table summary of the papers reported so far and make a brief overview in each section. On the basis of the data summarized in the tables, we discuss the changes in the annual number of publications in the last part of this review.

\section{Terminology of SWNTs}

Before going into the main subject of this review, the terminology of SWNTs is briefly introduced in this section. The properties of SWNTs are determined by the alignment of the hexagons as shown in Figure 1. For their electronic properties, armchair SWNTs have metallic property, and zigzag and chiral ones are either metallic or semiconducting, depending on the roll-up index (see Figure 2). While armchair and zigzag are achiral, a chiral SWNT has a pair of helical isomers as shown in Figures 1 and 2. Optically active SWNTs have been found by enrichment of either left- or right-handed structures [25-30].

Figure 1. (a) Armchair, (b) zigzag, and (c) chiral SWNTs. $P$ and $M$ describing the handedness of CNTs are defined in Figures 2 and 3.

(a)

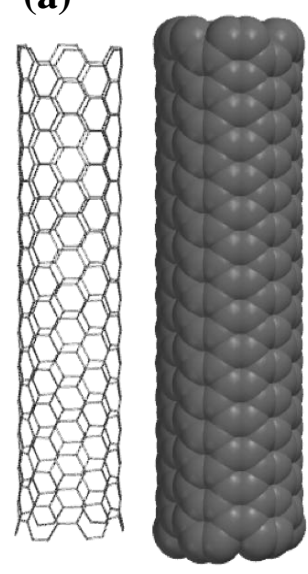

$(6,6)-S W N T$

armchair (b)

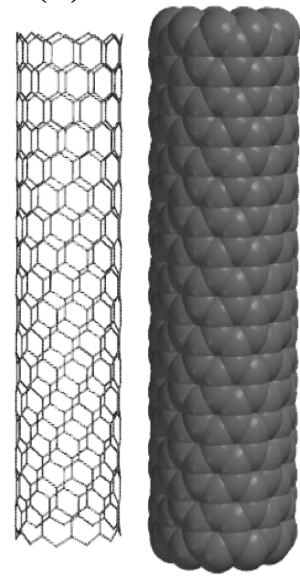

$(11,0)-$ SWNT

zigzag (c)

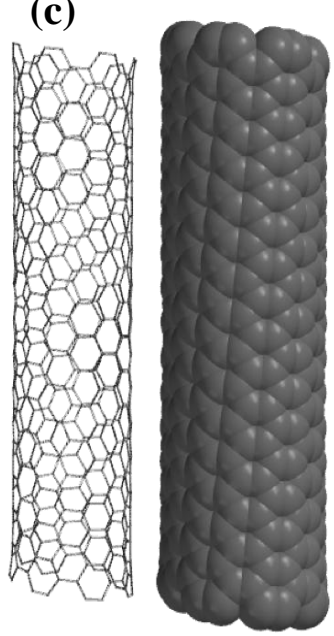

$(P)-(8,6)-S W N T$

chiral
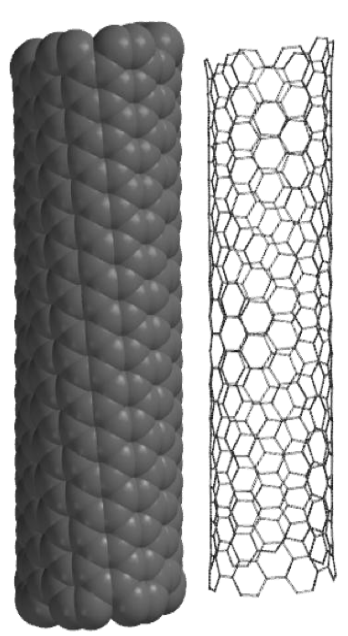

$(M)-(8,6)-$ SWNT

chiral 
Figure 2. $(M)$ - or $(P)-(n, m)$-SWNT defined by rolling up the graphene along the roll-up vector $\boldsymbol{C}_{h}$ from the front to the back, so that the front and back sides become the outer and inner surfaces of the SWNT, respectively.

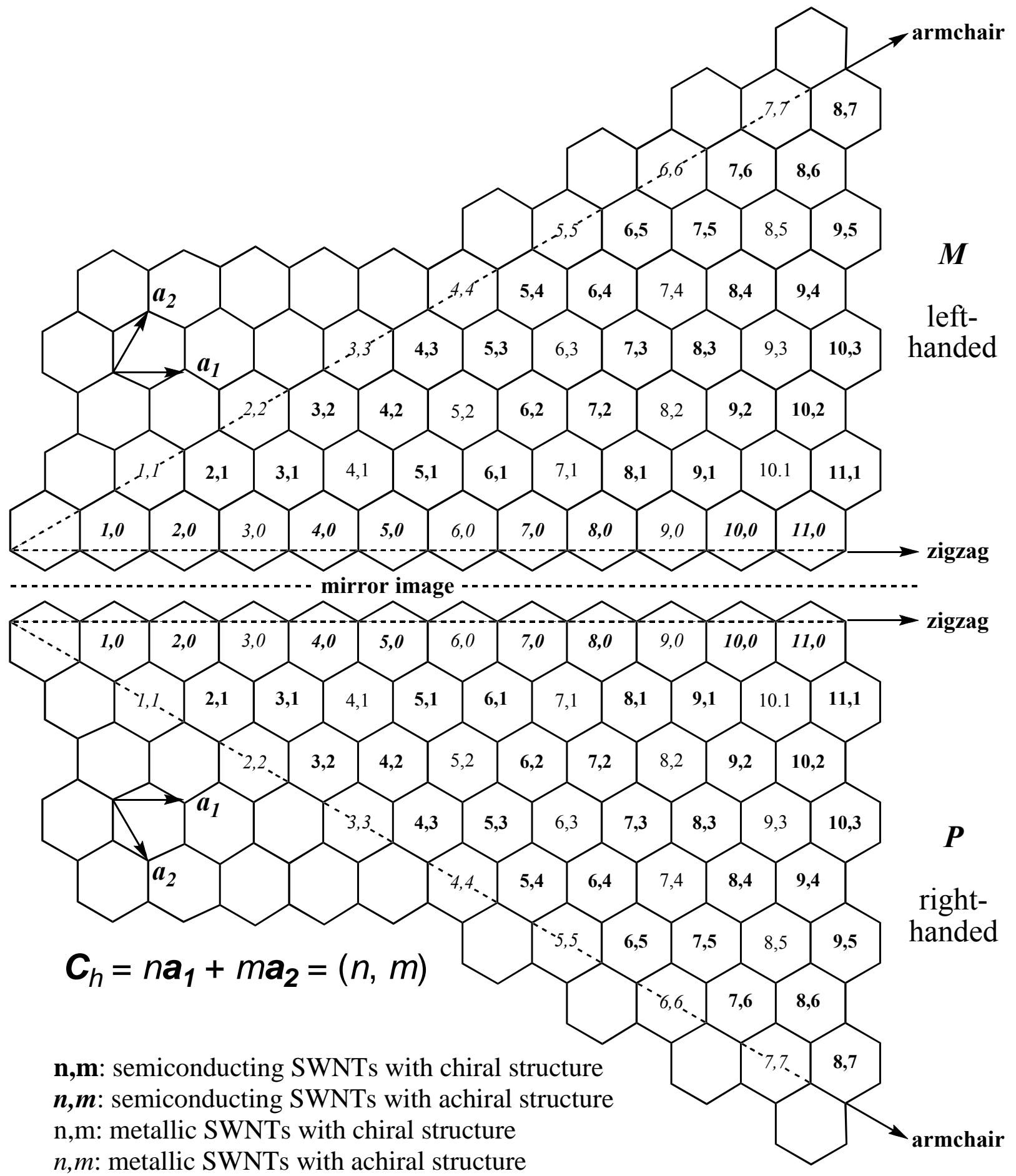

Since a SWNT can be prepared by rolling up a graphene into a seamless cylinder, the structure is defined by a roll-up vector $\boldsymbol{C}_{h}$ defined by two unit vectors $\boldsymbol{a}_{1}$ and $\boldsymbol{a}_{2} ; C_{h}=n \boldsymbol{a}_{1}+m \boldsymbol{a}_{2}$, where $n$ and $m$ are integers and designated as the roll-up index $(n, m)$ as shown in Figure 2 [31,32]. The $(n, m)$ and $\boldsymbol{C}_{h}$ have been referred to as "chiral" index (or simply "chirality") and "chiral" vector, respectively. However, the meaning of the "chiral" is not consistent with the original meaning defined by the 
International Union of Pure and Applied Chemistry (IUPAC); that is, "the geometric property of a rigid object of being non-superposable on its mirror image" [33]. Since this terminology is confusing, as Strano pointed out in the article [34], an explicit nomenclature is required to define the structures of CNTs. In this review, the terms of "chiral" and "chirality" are only used according to the definition of IUPAC mentioned above, and the term of $(n, m)$ is used for describing the roll-up index of SWNTs.

The handedness of chiral SWNTs is defined as $M$ and $P$ as follows. Every SWNT has three zigzag lines ( $\mathrm{Z}$ lines) as indicated as solid arrows in Figure 3. These $\mathrm{Z}$ lines cannot be superposed on their mirror-image in the case of chiral SWNTs, while they can be superposed in zigzag and armchair types. When two of the three $\mathrm{Z}$ lines are rotated to the left and the third $\mathrm{Z}$ line to the right, the chiral SWNT is designated as $M$ as shown in Figure 3a. Similarly, the chiral SWNT with two Z lines rotated to the right is $P$ as shown in Figure 3b. This terminology is based on $Z R$ and $Z L$ in the literature [31]. In this review, we propose $M$ and $P$ stereodescriptors according to the IUPAC nomenclature.

Figure 3. Definition of (a) $M$ (left-handed) and (b) $P$ (right-handed) chiral SWNTs. Three arrows and dashed line indicate zigzag lines and SWNT axis, respectively.

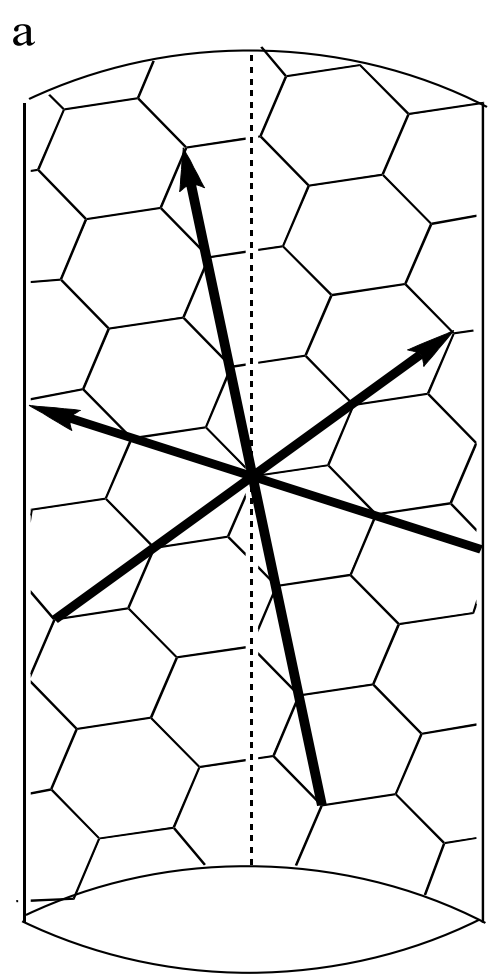

$M$

(left-handed) b

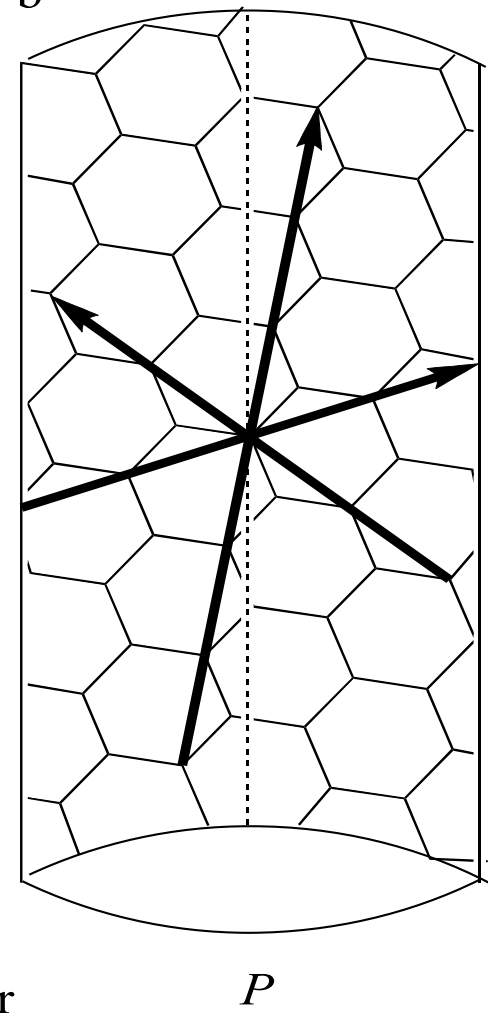

(right-handed)

\section{Physical Methods for Separation of Carbon Nanotubes}

\subsection{Electrophoresis}

Electrophoresis has been employed for separating various kinds of SWNTs, synthesized by laser vaporization (LV), arc discharge (AD), chemical vapor deposition (CVD) and HiPco (high pressure $\mathrm{CO}$ ) process, according mainly to electrical property $(\mathrm{M} / \mathrm{S}$ ) together with length and 
diameter as summarized in Table 1 [35,36]. Charged biological macromolecules are commonly separated by electrophoresis using gel in an electric field. In order to process SWNTs in the gel, the SWNTs have to be individually dispersed with aid of surfactant such as sodium dodecylsulfonate (SDS), sodium cholate (SC) and sodium dodecylbenzenesulfonate (SDBS). The M/S separation using this method utilized different polarizable characters between them under an electric field. Dielectrophoresis technique was first used for the alignment and purification of SWNT bundles in isopropyl alcohol $[37,38]$. It was extended to separation of individually dispersed SWNTs.

Table 1. Separation of SWNTs by electrophoresis.

\begin{tabular}{|c|c|c|c|}
\hline Reference & Separated object & SWNTs & Chemicals \\
\hline$[39,40]$ & $\mathrm{M} / \mathrm{S}$ & HiPco, LV & $\mathrm{SDS} / \mathrm{D}_{2} \mathrm{O}$ \\
\hline [41] & $\mathrm{M} / \mathrm{S}$ & LV & $\mathrm{DMF}$ \\
\hline$[42]$ & $\mathrm{M} / \mathrm{S}$ & CVD & DMF \\
\hline [43] & $\mathrm{M} / \mathrm{S}$ & $\mathrm{LV}$ & $\mathrm{SC} / \mathrm{D}_{2} \mathrm{O}$ \\
\hline [44] & length, diameter & HiPco & $\mathrm{SC} /$ water \\
\hline [45] & length & LV, HiPco & polyvinyl pyrrolidone (PVP) \\
\hline [46] & length & $\mathrm{AD}$ & SDS/water \\
\hline [47] & diameter & HiPco & SDS or PVP \\
\hline [48] & $\mathrm{M} / \mathrm{S}$ & HiPco & SDS/water \\
\hline [49] & $\mathrm{M} / \mathrm{S}$, diameter & HiPco & SDBS/water \\
\hline [50-52] & $\mathrm{M} / \mathrm{S}$ & HiPco & SDS/water \\
\hline [53-55] & $\mathrm{M} / \mathrm{S}$ & $\begin{array}{c}\text { LV, AD } \\
\text { HiPco }\end{array}$ & SDS/water \\
\hline$[56]$ & $\mathrm{M} / \mathrm{S}$ & $\mathrm{AD}$ & SDS/water \\
\hline$[57]$ & $\mathrm{M} / \mathrm{S}$ & HiPco & $\mathrm{SDBS} / \mathrm{D}_{2} \mathrm{O}$ \\
\hline$[58,59]$ & $\mathrm{M} / \mathrm{S}$ & HiPco, LV & Triton X-100, water \\
\hline$[60]$ & $\mathrm{M} / \mathrm{S}$ & HiPco & $\begin{array}{l}\text { SDS, cetyltrimethylammonium } \\
\text { bromide }\end{array}$ \\
\hline$[61]$ & $\mathrm{M} / \mathrm{S}$ & $\mathrm{AD}$ & Gum Arabic or PVP \\
\hline$[62]$ & diameter, length & HiPco & DNA or RNA \\
\hline
\end{tabular}

\subsection{Centrifugation}

This process is very powerful and versatile to separate SWNTs according to their electrical and structural properties such as M/S, diameter, length, $(n, m)$ and handedness [63]. In 2005, Arnold and Hersam reported the first example of density gradient ultracentrifugation (DGU) for separation of the diameter of SWNTs [64]. They successfully applied the process to the separation of M/S electrical property, $(n, m)$ structures and even handedness [25,65]. The methodology was extended to $(n, m)$ separation and enantiomer sorting of HiPco SWNTs [30]. The papers reported so far are summarized in Table 2. SDS and/or SC have been commonly used as detergents to dissolve SWNTs. In addition, iodixanol is required as a gradient-induced agent to the aqueous medium. Organic system was employed in only one example in the presence of polymer and heavily halogenated benzene in organic solvent [66]. Quite recently, facile M/S separation has been realized by use of SDS and agarose gel $[53,67]$. 
Table 2. Separation of SWNTs by density gradient ultracentrifugation (DGU).

\begin{tabular}{|c|c|c|c|}
\hline Reference & Separated object & SWNTs & Chemicals \\
\hline$[40,64,65,68-76]$ & $\mathrm{M} / \mathrm{S}$, diameter, $(6,5),(7,5)$ & $\begin{array}{c}\text { CoMoCAT, LV, HiPco, } \\
\text { AD }\end{array}$ & $\begin{array}{l}\text { SDS, SC/iodixanol in water, } \\
\text { DNA/iodixanol in water }\end{array}$ \\
\hline$[77,78]$ & $\mathrm{M} / \mathrm{S}$ & LV, HiPco, CoMoCAT & $\begin{array}{c}\text { sodium deoxycholate (SDC)/ } \\
\text { iodixanol in water }\end{array}$ \\
\hline [25] & handedness, $(6,4),(6,5)$ & CoMoCAT, AD & SC/iodixanol in water \\
\hline [30] & $\begin{array}{l}\text { handedness, }(6,4),(6,5), \\
(7,3),(9,1),(8,3),(9.2), \\
(7,5),(8,4),(10,2),(7,6)\end{array}$ & HiPco & SC, SDS/iodixanol in water \\
\hline [66] & $(7,5),(7,6),(10,5),(9,7)$ & LV, HiPco, CoMoCAT & $\begin{array}{l}\text { fluorene-based } \\
\text { polymer/chlorobenzene + } \\
\text { tribromotoluene }\end{array}$ \\
\hline [79] & $\mathrm{M} / \mathrm{S}$, diameter & HiPco & $\mathrm{SDS}, \mathrm{NaCl} /$ iodixanol in water \\
\hline [80] & $\mathrm{M} / \mathrm{S}$, diameter & $\mathrm{AD}$ & $\begin{array}{l}\text { sodium taurodeoxycholic } \\
\text { acid, SDS, SC/iodixanol in } \\
\text { water }\end{array}$ \\
\hline [81] & $\mathrm{M} / \mathrm{S}$ & $\mathrm{AD}$ & SC, SDS/sucrose in water \\
\hline [82] & $(6,5)$ & Co-MCM-41 & SC, SDS/iodixanol in water \\
\hline$[83]$ & diameter & HiPco & SDS, PVP/water \\
\hline$[84,85]$ & diameter & $\mathrm{AD}$ & SC/iodixanol in water \\
\hline [86] & DWNTs & $\begin{array}{c}\text { Mixture of SWNTs, } \\
\text { DWNTs and MWNTs }\end{array}$ & SC/iodixanol in water \\
\hline [87] & short length (about $7.5 \mathrm{~nm}$ ) & HiPco & PL-PEG/iodixanol in water \\
\hline [88] & length & CoMoCAT, HiPco, LV & SDC/iodixanol in water \\
\hline$[53,67]$ & $\mathrm{M} / \mathrm{S}$ & LV, AD, HiPco & SDS/agarose gel \\
\hline [89] & $(n, m)$ & CoMoCAT, HiPco, LV & SC/iodixanol in water \\
\hline [90] & length & CoMoCAT, HiPco, LV & SDC/iodixanol in water \\
\hline
\end{tabular}

\section{Chemical Methods for Separation of Carbon Nanotubes}

\subsection{Chromatography}

Chromatography was first employed for separation of CNTs by Duesberg and coworkers in 1998. In addition to removal of metallic impurities and amorphous carbon, length separation of SWNTs as well as MWNTs was accomplished by size exclusion chromatography (SEC) after dissolvation of CNTs in the presence of SDS [91-93]. In 2003, Zheng and coworkers separated DNA-wrapped SWNTs by ion-exchange chromatography (IEC) to realize $\mathrm{M} / \mathrm{S}$, length and diameter separations [94,95]. Quite recently, the IEC separation was extended to strict $(n, m)$ separation by applying appropriate sequences of DNA, providing many kinds of pure $(n, m)$ of SWNTs [96]. The separations of length and M/S by field flow fractionation (FFF) and optical trapping, respectively, are incorporated in this section, as shown in Table 3 [97-103]. 
Table 3. Separation of SWNTs by chromatography.

\begin{tabular}{cccc}
\hline Reference & Separated object & SWNTs & Chemicals \\
\hline$[104]$ & $(8,4)$ & FeRu-CVD & DNA, IEC \\
{$[105]$} & $(6,4),(9,1),(6,5)$ & CoMoCAT & DNA, SEC + IEC \\
{$[96,106]$} & $(n, m)$ & HiPco & DNA, IEC \\
{$[94,95,107-109]$} & M/S, diameter, length & HiPco & DNA, IEC \\
{$[110]$} & $(6,5)$ & CoMoCAT & DNA, IEC \\
{$[111]$} & M/S, diameter, $(n, m)$ & HiPco & DNA, SEC + IEC \\
{$[112-114]$} & length & & DNA, SEC \\
{$[115]$} & length & HiPco & octadecylamine/THF, GPC \\
{$[91-93,116]$} & length & LV, AD, MWNTs & SDS, SEC \\
{$[117]$} & length & LV & Triton X-100, SEC \\
{$[44,118]$} & length, diameter & HiPco, LV & SC, SEC \\
{$[119]$} & length & CoMoCAT, HiPco, LV, AD & DNA, SEC \\
{$[120]$} & M/S & HiPco functionalized with & SDS/o-dichlorobenzene, silica \\
& & t-aryl groups group & gel chromatography \\
{$[121]$} & M/S & HiPco & SDS/agarose gel beads \\
{$[40]$} & M/S & LV & SDS, SC/SEC \\
{$[97]^{\mathrm{a}}$} & length & LV & Triton X-100, water \\
{$[98]^{\mathrm{a}}$} & length & AD (SWNTs), CVD (MWNTs) & SDS, water \\
{$[99]^{\mathrm{a}}$} & length & AD & Triton X-100, water \\
{$[100]^{\mathrm{a}}$} & length & CNT (Carbolex $)$ & Triton X-100, water \\
{$[101]^{\mathrm{a}}$} & length & CoMoCAT, HiPco, LV, AD & DNA, water \\
{$[102]^{\mathrm{a}}$} & length & functionalized MWNTs & water (pH = 10) \\
{$[103]^{\mathrm{b}}$} & M/S & HiPco & DNA, water \\
\hline
\end{tabular}

${ }^{\mathrm{a}}$ FFF: Field-flow fractionation, ${ }^{\mathrm{b}}$ Optical trapping.

\subsection{Selective Solubilization}

Although SWNTs are not solubilized in any solvents, they can be dissolved into solvent in the presence of a solubilizing agent [12-17,122]. If the agent can recognize the electrical property and/or structural character of SWNTs, separation of SWNTs can be realized through the extraction [123]. The solubilizing agents reported so far include simple molecule such as alkylamine for M/S separation [124-130], polymers such as fluorene-based ones for extracting specific ( $n, m)$ structure [66,89,131-133], poly(phenylenevinylene) [134-138] and designed host molecules such as tweezer-type ones for discrimination of diameter, $(n, m)$ and handedness [26,28,29,34]. Although the SWNTs have been optically resolved by selective solubilization with chiral nanotweezers [26-29] and DGU with chiral detergent [25,30], the absolute configuration of the resolved SWNTs were determined only by theoretical calculations [139]. Therefore, experimental evidence is required to assign the handedness as Weisman pointed out in his recent paper [30]. The papers of selective solubilization are summarized in Table 4. 
Table 4. Separation of SWNTs by selective solubilization.

\begin{tabular}{|c|c|c|c|}
\hline Reference & Separated object & SWNTs & Chemicals \\
\hline$[53,140]$ & $\mathrm{M} / \mathrm{S}$ & LV & SDS/water \\
\hline [124-127] & $\mathrm{M} / \mathrm{S}$ & LV, HiPco & octadecylamine, octadecylamine/THF \\
\hline$[128-130]$ & $\mathrm{M} / \mathrm{S}(87 \% \mathrm{M})$ & HiPco, CoMoCAT & octylamine/THF \\
\hline [141] & $\mathrm{M} / \mathrm{S}$ & $\mathrm{AD}$ & amine- or phenyl-terminated $\mathrm{SiO}_{2}$ \\
\hline$[142,143]$ & $\mathrm{M} / \mathrm{S}$ & $\mathrm{LV}, 1.1-1.6 \mathrm{~nm}$ & bromine, triton X-100/water \\
\hline$[130,144,145]$ & $\mathrm{M} / \mathrm{S}$ & $\mathrm{AD}$ & porphyrin/ $\mathrm{CHCl}_{3}$, pyrene/THF \\
\hline$[146,147]$ & $(8,6) 85 \%$ & HiPco & flavin mononucleotide $/ \mathrm{D}_{2} \mathrm{O}$ \\
\hline [131] & $(7,5)$ & Co-MCM-41 & fluorene-based polymers/toluene \\
\hline$[132,133]$ & $\begin{array}{l}(7,5),(8,6) \\
\quad(10,5)\end{array}$ & CoMoCAT, HiPco & $\begin{array}{l}\text { fluorene-based polymers/toluene, xylene, THF, } \\
\text { chloroform }\end{array}$ \\
\hline$[148,149]$ & $\begin{array}{l}(8,6),(7,6) \\
\text { diameter }\end{array}$ & HiPco & $\begin{array}{l}\text { pentacene-quaterrylene- and naphthopentaphene- } \\
\text { based amphiphiles, SDS/water }\end{array}$ \\
\hline [66] & $\begin{array}{l}(7,5),(7,6) \\
(10,5),(9,7)\end{array}$ & $\begin{array}{l}\text { LV, HiPco, } \\
\text { CoMoCAT }\end{array}$ & $\begin{array}{c}\text { fluorene-based polymer/chlorobenzene }+ \\
\text { tribromotoluene }\end{array}$ \\
\hline [89] & $(n, m)$ & $\begin{array}{l}\text { LV, HiPco, } \\
\text { CoMoCAT }\end{array}$ & fluorene-based polymer/toluene \\
\hline [134-137] & diameter, $\mathrm{M} / \mathrm{S}$ & $\mathrm{AD}, \mathrm{HiPco}$ & poly(phenylenevinylene)/toluene \\
\hline$[138]$ & $\begin{array}{l}(11,6),(11,7) \\
\quad(12,6)\end{array}$ & HiPco & poly(phenylenevinylene)/THF \\
\hline$[150,151]$ & diameter & HiPco & reversible cyclic peptide/water \\
\hline [152] & diameter & $\mathrm{AD}$ & $\eta$-cyclodextrin $/ \mathrm{D}_{2} \mathrm{O}$ \\
\hline$[153]$ & diameter & SWNTs & pentacene-based molecular tweezers/toluene \\
\hline$[154]$ & $\mathrm{M} / \mathrm{S}$ & $\mathrm{AD}$ & $\begin{array}{l}\text { potassium salt of coronene tetracarboxylic } \\
\text { acid/water }\end{array}$ \\
\hline [155] & diameter & HiPco & chitosan polymer/water \\
\hline [156] & diameter & HiPco & porphyrinic polypeptides/DMF \\
\hline [157] & diameter & HiPco & ruthenium metallodendrimer/DMF \\
\hline [27] & helicity, diameter & CoMoCAT & chiral monoporphyrin/methanol \\
\hline$[26,28,29,34]$ & helicity, $(\mathrm{n}, \mathrm{m})$ & CoMoCAT & chiral nanotweezers/metanol \\
\hline$[158,159]$ & diameter & HiPco, AD & $\begin{array}{l}\text { diamine-terminated oligomeric poly(ethylene } \\
\text { glycol)/water }\end{array}$ \\
\hline [160] & length & HiPco & $\begin{array}{l}\text { tetraoctylammonium bromide/ethyl acetate or } \\
\text { toluene }\end{array}$ \\
\hline [161] & $(8,4)$, diameter & $\begin{array}{l}\text { CoMoCAT, } \\
\text { HiPco }\end{array}$ & $\begin{array}{c}\text { heparin/water } \\
\text { heparin, SDBS/water }\end{array}$ \\
\hline [162] & $\mathrm{M} / \mathrm{S}$ & CoMoCAT & DNA/water \\
\hline$[130,163]$ & $\mathrm{M} / \mathrm{S}$, diameter & HiPco & pyrene derivative/water \\
\hline [164] & diameter & CoMoCAT, HiPco & pyrene derivative/water \\
\hline [165] & diameter & HiPco & SDS, SDBS or SC in water \\
\hline [166] & diameter & HiPco & $\mathrm{ClSO}_{3} \mathrm{H} / \mathrm{CH}_{3} \mathrm{SO}_{3} \mathrm{H}$ \\
\hline
\end{tabular}




\subsection{Selective Reaction}

Most of the selective reactions for SWNT separation [123,167] are classified into the following three types of chemical and physical processes; selective oxidation in the presence of $\mathrm{H}_{2} \mathrm{O}_{2}$ [168-172], $\mathrm{OsO}_{4}$ [173], $\mathrm{H}_{2} \mathrm{SO}_{4} / \mathrm{HNO}_{3}$ [174-177], $\mathrm{HNO}_{3}$ [178], ozone [179,180], $\mathrm{AuCl}_{4}^{-}$[181], $\mathrm{NaClO}_{\mathrm{x}}$ [182] and air (high temperature) [183,184] for $\mathrm{M} / \mathrm{S}$, diameter and $(n, m)$ selections, selective reaction with nitronium ion [185,186], $\mathrm{NO}_{2}$ [187], carbene [188,189], diazonium salt [58,109,190-202], fluorine [203], triethylsilane [204], fluorinated olefin [205], $\mathrm{SO}_{3}$ [206], $\mathrm{RLi}$ and $\mathrm{RMgX}$ [207], and azomethine ylide [208] for M/S separation, selective break-down of either metallic or semiconducting SWNTs by use of electricity [209-211], plasma [212,213], laser [214,215], microwave [174,216,217] and Xe-lamp [218], and electrochemical doping with Li [219] and cations [220,221] to specific $(n, m)$ and diameter. The literature is summarized in Table 5.

Table 5. Separation of SWNTs by selective reaction.

\begin{tabular}{|c|c|c|c|}
\hline Reference & Separated object & SWNTs & Chemicals \\
\hline$[130,168]$ & $\mathrm{M} / \mathrm{S}$ & HiPco & $\mathrm{H}_{2} \mathrm{O}_{2 / \text { water at }} 90^{\circ} \mathrm{C}$ \\
\hline [169] & diameter, $(n, m)$ & HiPco & air at $450{ }^{\circ} \mathrm{C}, \mathrm{H}_{2} \mathrm{O}_{2 / \text { water at }} 90^{\circ} \mathrm{C}$ \\
\hline [170] & diameter & HiPco & $\mathrm{H}_{2} \mathrm{O}_{2}$, light irradiation \\
\hline [171] & $(n, m)$ & HiPco, CoMoCAT & $\mathrm{H}_{2} \mathrm{O}_{2}, \mathrm{SC}$ or $\mathrm{SC} / \mathrm{SDS}$ in $\mathrm{D}_{2} \mathrm{O}$ \\
\hline [172] & diameter & HiPco & $\mathrm{H}_{2} \mathrm{O}_{2}+$ light \\
\hline [173] & $\mathrm{M} / \mathrm{S}$ & HiPco & $\mathrm{OsO}_{4}, \mathrm{UV}$ \\
\hline [182] & $\mathrm{M} / \mathrm{S}$ & $\mathrm{AD}$ & $\mathrm{NaClO}_{\mathrm{x}} / 1$-methyl-2-pyrrolidone \\
\hline [174] & $\mathrm{M} / \mathrm{S}$, diameter & HiPco & $\begin{array}{c}\text { acid mixture }\left(\mathrm{H}_{2} \mathrm{SO}_{4} / \mathrm{HNO}_{3}\right) \text { under } \\
\text { microwave irradiation }\end{array}$ \\
\hline [175] & $\mathrm{M} / \mathrm{S}$ & HiPco & acid mixture $\left(\mathrm{H}_{2} \mathrm{SO}_{4} / \mathrm{HNO}_{3}\right)$ \\
\hline$[176,177]$ & diameter & HiPco & $\begin{array}{c}\text { acid mixture }\left(\mathrm{H}_{2} \mathrm{SO}_{4 /} \mathrm{HNO}_{3}\right) \text { at } 35-55^{\circ} \mathrm{C} \\
\text { under sonication }\end{array}$ \\
\hline [178] & $\mathrm{M} / \mathrm{S}$ & HiPco & $\mathrm{HNO}_{3}$ at $135^{\circ} \mathrm{C}$ \\
\hline$[179,180]$ & diameter & HiPco & ozone in methanol at $-78^{\circ} \mathrm{C}$ \\
\hline [181] & $(6,5)$ & HiPco & $\mathrm{AuCl}_{4}^{-}, \mathrm{SC} /$ water \\
\hline [183] & diameter & LV & air at $350-550{ }^{\circ} \mathrm{C}, \mathrm{HNO}_{3}$ at $120^{\circ} \mathrm{C}$ \\
\hline$[184]$ & & HiPco & air at $460-620^{\circ} \mathrm{C}$ \\
\hline$[185,186]$ & $\mathrm{M} / \mathrm{S}$ & HiPco & $\begin{array}{c}\mathrm{NO}_{2} \mathrm{SbF}_{6} \text { or } \mathrm{NO}_{2} \mathrm{BF}_{4} \text { in tetramethylene } \\
\text { sulfone/chloroform }\end{array}$ \\
\hline [187] & $\mathrm{M} / \mathrm{S}$, diameter & SWNTs & $\mathrm{NO}_{2}$ \\
\hline$[188,189]$ & $\mathrm{M} / \mathrm{S}$ & HiPco & dichlorocarbene in dichlorobenzene \\
\hline$[190,194,197-199]$ & $\mathrm{M} / \mathrm{S}$ & HiPco & diazonium salt/water \\
\hline$[191]$ & $\mathrm{M} / \mathrm{S}$ & $\mathrm{AD}$ & $\begin{array}{l}\text { diazonium salt of 4-heptadecafluorooctyl- } \\
\text { aniline/perfluorohexane }\end{array}$ \\
\hline$[192,195]$ & $\mathrm{M} / \mathrm{S}$ & HiPco, AD & $\begin{array}{l}\text { 4-nitrobenzenediazonium salt in DMF, } \\
\text { 4-aminobenzylamine }\end{array}$ \\
\hline$[193,200]$ & $\mathrm{M} / \mathrm{S}$ & CVD & $\begin{array}{c}\text { 4-bromobenzenediazonium } \\
\text { tetrafluoroborate in water }\end{array}$ \\
\hline
\end{tabular}


Table 5. Cont.

\begin{tabular}{|c|c|c|c|}
\hline Reference & Separated object & SWNTs & Chemicals \\
\hline$[58,109,201]$ & $\mathrm{M} / \mathrm{S}$ & HiPco & 4-hydroxybenzenediazonium salt \\
\hline [196] & $\mathrm{M} / \mathrm{S}$ & HiPco & $\begin{array}{l}\text { SC, 4-dodecyloxybenzenediazonium } \\
\text { tetrafluoroborate in water }\end{array}$ \\
\hline [202] & $\mathrm{M} / \mathrm{S}$, diameter & HiPco & $\begin{array}{l}\text { SDS, 4-chloro- and 4-nitrophenyldiazonium } \\
\text { salts in water }\end{array}$ \\
\hline [203] & $\mathrm{M} / \mathrm{S}$, diameter & HiPco & fluorine gas \\
\hline [204] & $\mathrm{M} / \mathrm{S}$ & HiPco & triethylsilane at room temperature \\
\hline [205] & $\mathrm{M} / \mathrm{S}$ & HiPco & $\begin{array}{c}\text { perfluoro 2-(fluorosulfonylethoxy)propyl } \\
\text { vinyl ether at } 215^{\circ} \mathrm{C}\end{array}$ \\
\hline [206] & $\mathrm{M} / \mathrm{S}$ & HiPco & $\mathrm{SO}_{3}$ at $400{ }^{\circ} \mathrm{C}$ \\
\hline$[130,208]$ & $\mathrm{M} / \mathrm{S}$ & HiPco & azomethine ylide/THF at $65^{\circ} \mathrm{C}$ \\
\hline$[207]$ & $\mathrm{M} / \mathrm{S}$, diameter & HiPco & $\mathrm{RLi}, \mathrm{RMgX}$ in cyclohexane \\
\hline$[209-211]$ & $\mathrm{M} / \mathrm{S}$ & MWNTs, SWNTs & current-induced electrical breakdown \\
\hline [212] & $\mathrm{M} / \mathrm{S}$ & CVD & methane plasma at $400{ }^{\circ} \mathrm{C} /$ annealing at $600{ }^{\circ} \mathrm{C}$ \\
\hline [213] & $\mathrm{M} / \mathrm{S}$ & $\mathrm{AD}$ & hydrogen plasma \\
\hline [214] & $(n, m)$ & CVD & laser irradiation \\
\hline [215] & $\mathrm{M} / \mathrm{S}$ & CoMoCAT, HiPco, LV & laser irradiation \\
\hline [218] & $\mathrm{M} / \mathrm{S}$ & Fe-catalyzed CVD & Xe lamp \\
\hline [216] & & CoMoCAT & microwave irradiation \\
\hline$[174,217]$ & $\mathrm{M} / \mathrm{S}$, diameter & HiPco & microwave irradiation \\
\hline [219] & diameter & HiPco & Li at $473{ }^{\circ} \mathrm{C}$ \\
\hline [220] & $(n, m)$ & HiPco & SDS in $\mathrm{D}_{2} \mathrm{O} /$ salt $\left(\mathrm{NaCl}, \mathrm{MgSO}_{4}, \mathrm{ErCl}_{3}\right)$ \\
\hline [221] & diameter & HiPco & $\begin{array}{c}\mathrm{LiClO}_{4},\left(\mathrm{CH}_{3}\right)_{4} \mathrm{NBF}_{4}, \mathrm{n}-\mathrm{Bu}_{4} \mathrm{NClO}_{4} \\
\mathrm{n}-\mathrm{Oct}_{4} \mathrm{NClO}_{4}, \text { ionic liquid in } \mathrm{CH}_{3} \mathrm{CN}\end{array}$ \\
\hline [222] & $\mathrm{M} / \mathrm{S}$ & $\mathrm{AD}$ & $\begin{array}{l}\text { aromatic or aliphatic solvent with } \\
\text { electron-withdrawing or -donating groups }\end{array}$ \\
\hline [223] & $(n, m)$ & HiPco & $\begin{array}{l}\text { TCNQ, TFTCNQ } \\
\qquad \mathrm{AB}^{\mathrm{b}} \text {, mordant yellow } 10 \text { and }\end{array}$ \\
\hline [224] & $\mathrm{M} / \mathrm{S}$ & $(10,0),(6,6)$ & naphthalene, anthracene, TCNQ and DDQ \\
\hline
\end{tabular}

a 2, 3, 5, 6-tetrafluoro-7, 7, 8, 8-tetracyanoquinodimethane, ${ }^{\mathrm{b}}$ 4-amino-1, 1-azobenzene-3, 4-disulfonic acid.

\section{Concluding Remarks}

Separation of SWNTs has been described in this review. The related papers reported so far are classified into the following five methods; electrophoresis (Chapter 3.1), centrifugation (3.2), chromatography (4.1), selective solubilization (4.2) and selective reaction (4.3). All the data, summarized in Tables 1-5, will be analyzed on the basis of Figures 4-6.

Changes in the annual number of publications from 1998 to 2009 are shown in Figure 4. The first few reports, published in 1998-1999, dealt with length separation of CNTs by chromatography and the related technique. CNTs were solubilized by use of sonication in the presence of surfactant in 1997 [225,226], making the SEC [91-93] and FFF [97] separations possible. The first papers on selective solubilization by polymer wrapping [134] and electrophoresis of polymer-wrapped SWNTs [45] were published in 2000 and 2001, respectively. The annual number of publications is less 
than 10 until 2002. During this period, about $60 \%$ of the papers focus on length separation, while investigations started on diameter and M/S separations (Figure 5). Noteworthy is that the first M/S separation was accomplished by electrical breakdown in 2001 [209,210]. In 2003, the number of papers suddenly leapt to more than 15 papers (Figure 4). This is probably because individualization of SWNTs in aqueous solution and the spectroscopic analysis were accomplished in 2002 by Smalley and Weisman [122,227]. The findings greatly facilitate more precise evaluation of the distribution of diameters and $(n, m)$ structures of the SWNTs before and after separation. Novel methods of selective reaction of carbenes and diazonium salts with metallic SWNTs were devised in 2003 [188-190,194], also increasing the number of publications in 2003 (Figure 4). Especially, publications related to M/S and diameter separations increased remarkably in 2003, as shown in Figure 5. In 2005 and 2006, the first papers of DGU were published by Hersam and coworkers [64,65], causing a sudden increase of the number of papers to more than 25 in 2007 (Figure 4). Fluorene-based polymers also found to extract the specific structure in 2007 [132]. These novel methodologies realized precise $(n, m)$ separation and enhanced the number of publications related to the $(n, m)$ separation shown in Figure 5 . In the same year, optically active SWNTs were obtained for the first time by separating the handedness of chiral nanotubes [29]. Conclusively, the changes in annual number of publications shown in Figures 4 and 5 indicate clearly that new findings on evaluation and separation of SWNTs stimulated the researchers in this field to increase the number of publications. The annual number of publications in this field is still increasing as shown in Figures 4 and 5. Several papers have already appeared in the beginning of 2010 [30,154,161,164].

Figure 4. Annual change in number of publications in the following five methods; electrophoresis (3-1), centrifugation (3-2), chromatography (4-1), selective solubilization (4-2) and selective reaction (4-3).

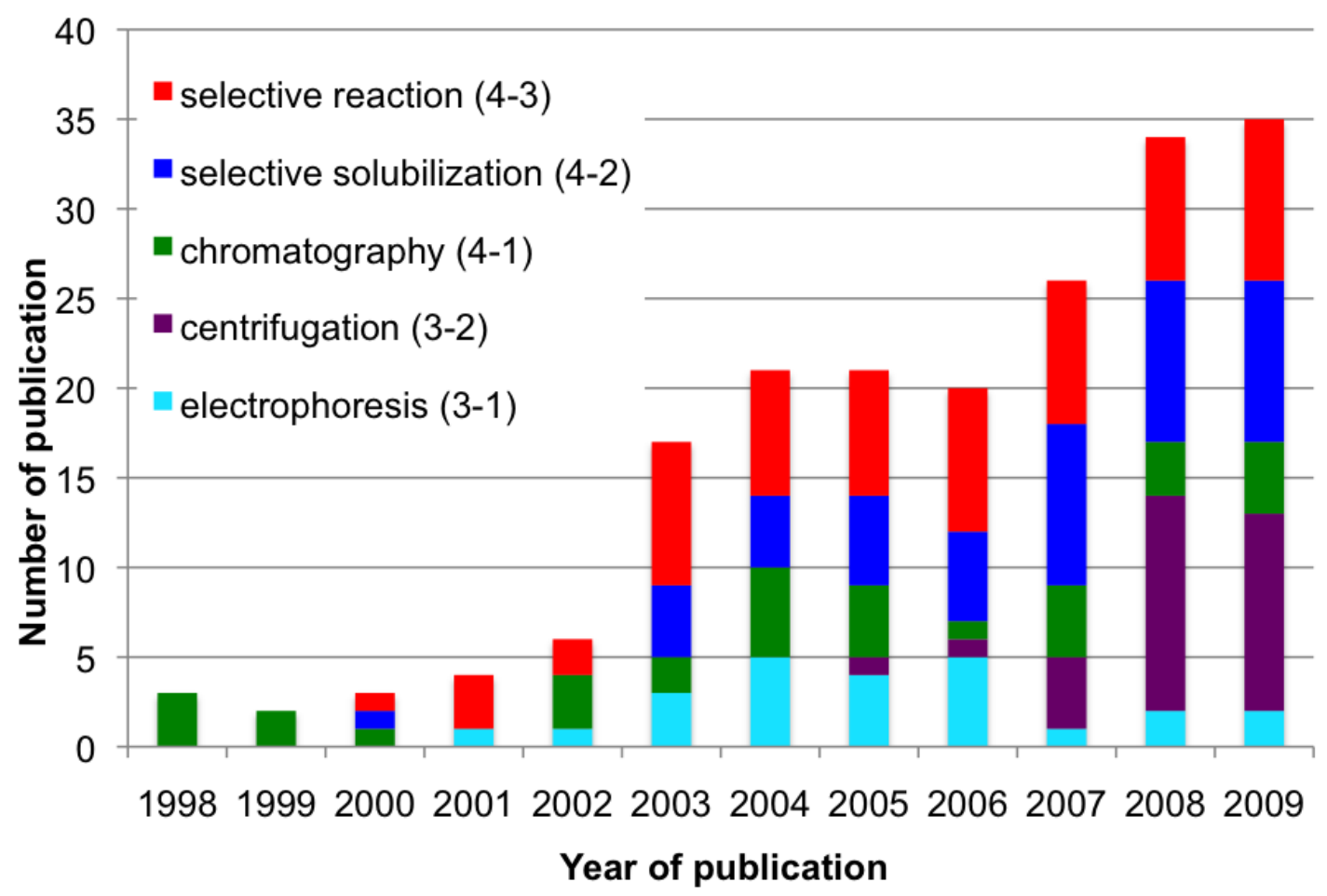


Figure 5. Annual change in number of publications in the following targeted objects to be separated; M/S, length, diameter, $(n, m)$ and handedness.

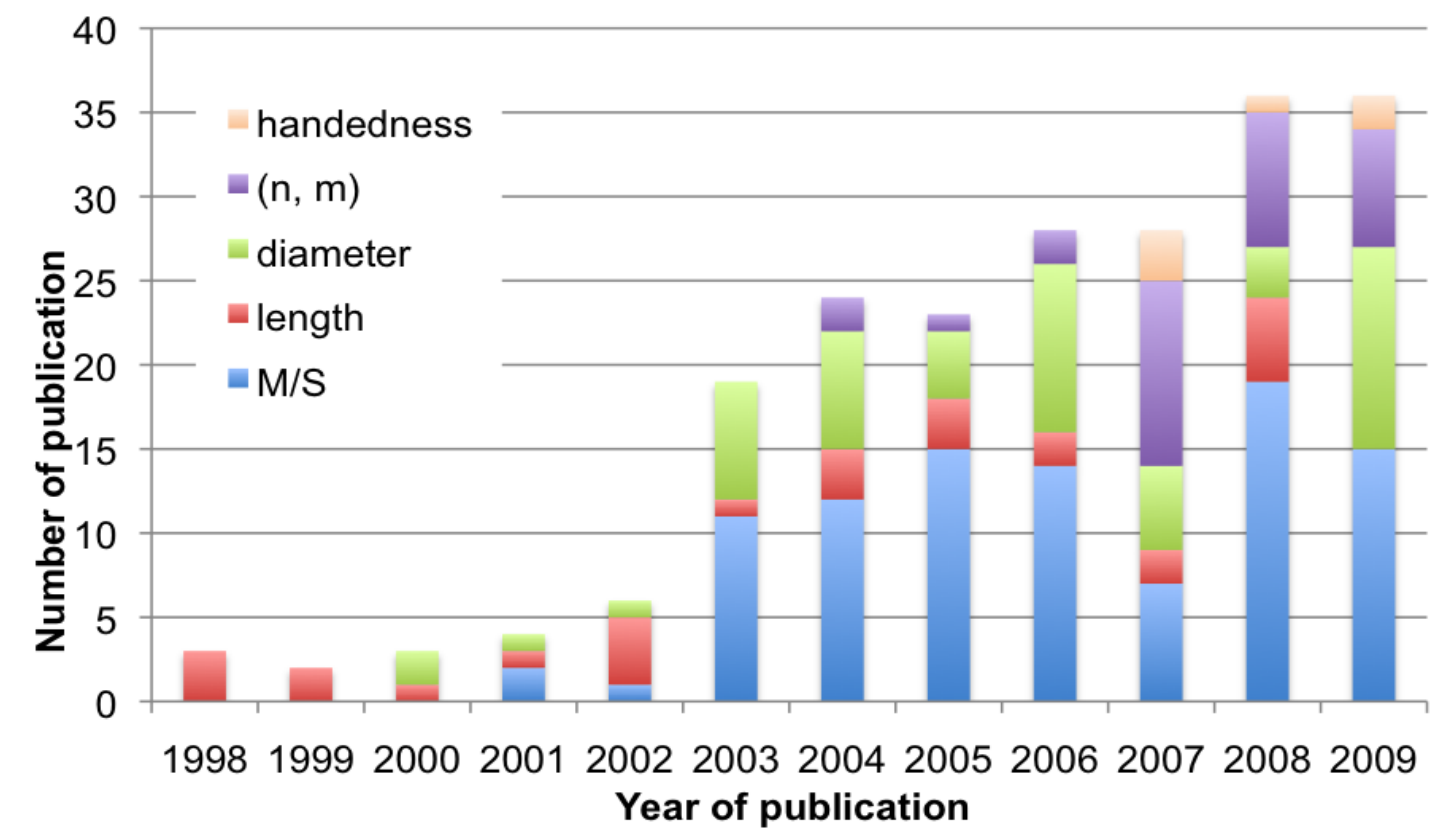

Figure 6. Rate in targeted object of SWNTs to be separated in the following five methods; electrophoresis (3-1), centrifugation (3-2), chromatography (4-1), selective solubilization (4-2) and selective reaction (4-3).

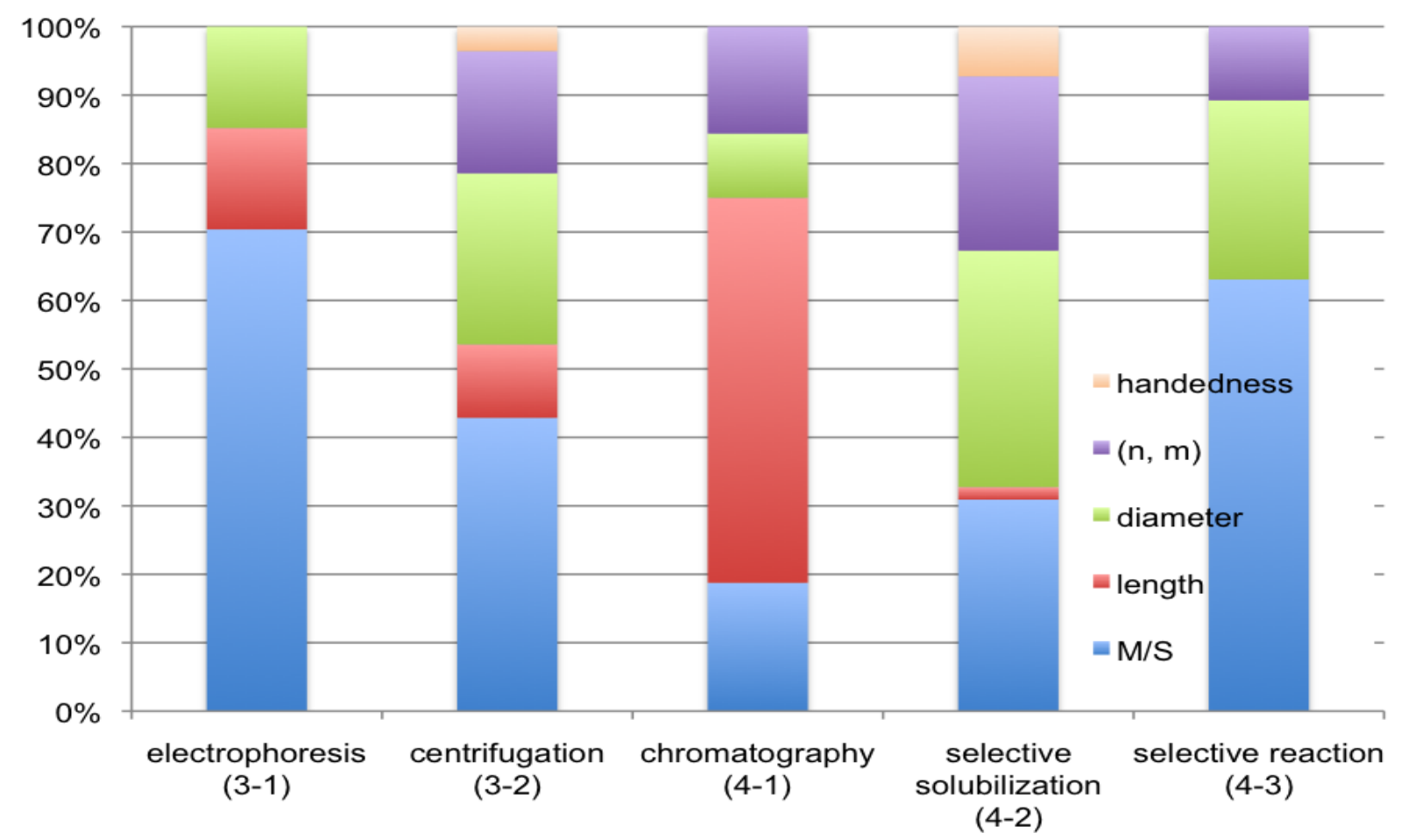

Figure 6 summarizes the rates of the separated objects in SWNTs in each of the five separation methods; electrophoresis, centrifugation, chromatography, selective solubilization and selective reaction. The rate is different among these methods as shown in the figure; for example, 
electrophoresis and selective reaction have been employed mainly for M/S separation, while length separation has been carried out mostly by chromatography. Centrifugation has been used for separating SWNTs according to a variety of structural and electrical features including $(n, m)$ and even handedness. However, the method is not considered to be suitable for large-scale separation. For M/S separation, scalable methods have been reported recently by Kataura and coworkers [140]. A more facile method to obtain specific $(n, m)$ in large quantities is awaited in view of electrical and optical applications of SWNTs.

\section{References and Notes}

1. Bachilo, S.M.; Balzano, L.; Herrera, J.E.; Pompeo, F.; Resasco, D.E. Weisman, R.B. Narrow $(n, m)$-distribution of single-walled carbon nanotubes grown using a solid supported catalyst. J. Am. Chem. Soc. 2003, 125, 11186-11187.

2. Wang, B.; Poa, C.H.P.; Wei, L.; Li, L.J.; Yang, Y.; Chen, Y. $(n, m)$ selectivity of single-walled carbon nanotubes by different carbon precursors on co-mo catalysts. J. Am. Chem. Soc. 2007, 129, 9014-9019.

3. Ciuparu, D.; Chen, Y.; Lim, S.; Haller, G.L.; Pfefferle, L. Uniform-diameter single-walled carbon nanotubes catalytically grown in cobalt-incorporated mcm-41. J. Phys. Chem. B 2004, 108, 503-507.

4. Luo, Z.T.; Pfefferle, L.D.; Haller, G.L.; Papadimitrakopoulos, F. $(n, m)$ abundance evaluation of single-walled carbon nanotubes by fluorescence and absorption spectroscopy. J. Am. Chem. Soc. 2006, 128, 15511-15516.

5. Takagi, D.; Kobayashi, Y.; Homma, Y. Carbon nanotube growth from diamond. J. Am. Chem. Soc. 2009, 131, 6922-6923.

6. Liu, B.; Ren, W.; Gao, L.; Li, S.; Pei, S.; Liu, C.; Jiang, C.; Cheng, H.M. Metal-catalyst-free growth of single-walled carbon nanotubes. J. Am. Chem. Soc. 2009, 131, 2082-2083.

7. Huang, S.; Cai, Q.; Chen, J.; Qian, Y.; Zhang, L. Metal-catalyst-free groth of single-walled carbon nanotubes on substrates. J. Am. Chem. Soc. 2009, 131, 2094-2095.

8. Hirsch, A. Groth of single-walled carbon nanotubes without a metal catalyst-A surprising discovery. Angew. Chem. Int. Ed. 2009, 48, 5403-5404.

9. Liu, B.; Ren, W.; Liu, C.; Sun, C.H.; Gao, L.; Li, S.; Jiang, C.; Cheng, H.M. Growth velocity and direct length-sorted growth of short single-walled carbon nanotubes by a metal-catalyst-free chemical vapor deposition process. ACS Nano 2009, 3, 3421-3430.

10. Harutyunyan, A.R.; Chen, G.; Paronyan, T.M.; Pigos, E.M.; Kuznetsov, O.A.; Hewaparakrama, K.; Kim, S.M.; Zakharov, D.; Stach, E.A.; Sumanasekera, G.U. Preferential growth of single-walled carbon nanotubes with metallic conductivity. Science 2009, 326, 116-120.

11. Hong, G.; Zhang, B.; Peng, B.; Zhang, J.; Choi, W.M.; Choi, J.Y.; Kim, J.M.; Liu, Z. Direct groth of semiconducting single-walled carbon nanotube array. J. Am. Chem. Soc. 2009, 131, 14642-14643.

12. Kharisov, B.I.; Kharissova, O.V.; Gutierrez, H.L.; Méndez, U.O. Recent advances on the soluble carbon noatubes. Ind. Eng. Chem. Res. 2009, 48, 572-590. 
13. Nakashima, N.; Fujigaya, T. Fundamentals and applications of soluble carbon nanotubes. Chem. Lett. 2007, 36, 692-697.

14. Nakashima, N. Soluble carbon nanotubes. Int. J. Nanosci 2005, 4, 119-137.

15. Murakami, H.; Nakashima, N. Soluble carbon nanotubes and their applications. J. Nanosci. Nanotechnol. 2006, 6, 16-27.

16. Liu, P. Modifications of carbon nanotubes with polymers. Eur. Polym. J. 2005, 41, 2693-2703.

17. Tasis, D.; Tagmatarchis, N.; Georgakilas, V.; Prato, M. Soluble carbon nanotubes. Chemistry 2003, 9, 4000-4008.

18. Hersam, M.C. Progress towards monodisperse single-walled carbon nanotubes. Nat. Nanotechnol. 2008, 3, 387-394.

19. Campidelli, S.; Meneghetti, M.; Prato, M. Separation of metallic and semiconducting single-walled carbon nanotubes via covalent functionalization. Small 2007, 3, 1672-1676.

20. Krupke, R.; Hennrich, F. In Chemistry of Carbon Nanotubes; Basiuk, V.A., Basiuk, E.V., Eds.; American Scientific Publishers: Stevenson Ranch, CA, USA, 2008; Volume 3, pp. 129-139.

21. Krupke, R.; Hennrich, F. Separation techniques for carbon nanotubes. Adv. Engineering Mater. 2005, 7, 111-116.

22. Papadimitrakopoulos, F.; Ju, S.Y. Purity rolled up in a tube. Nature 2007, 450, 486-487.

23. Haddon, R.C.; Sippel, J.; Rinzler, A.G.; Papadimitrakopoulos, F. Purification and separation of carbon nanotubes. MRS Bull. 2004, 29, 252-259.

24. Rao, C.N.R.; Voggu, R.; Govindaraj, A. Selective generation of single-walled carbon nanotubes with metallic, semiconducting and other unique electronic properties. Nanoscale 2009, 1, 96-105.

25. Green, A.A.; Duch, M.C.; Hersam, M.C. Isolation of single-walled carbon nanotube enantiomers by density differentiation. Nano Res. 2009, 2, 69-77.

26. Peng, X.; Komatsu, N.; Kimura, T.; Osuka, A. Simultaneous enrichments of optical purity and (n, m) abundance of swnts through extraction with 3,6-carbazolylene-bridged chiral diporphyrin nanotweezers. ACS Nano 2008, 2, 2045-2050.

27. Peng, X.; Komatsu, N.; Kimura, T.; Osuka, A. Optical resolution and diameter-based enrichment of single-walled carbon nanotubes through simultaneous recognition of their helicity and diameter with chiral monoporphyrin. J. Phys. Chem. C 2009, 113, 9108-9113.

28. Peng, X.; Komatsu, N.; Kimura, T.; Osuka, A. Improved optical enrichment of swnts through extraction with chiral nano-tweezers of 2,6-pyridylene-bridged diporphyrins. J. Am. Chem. Soc. 2007, 129, 15947-15953.

29. Peng, X.; Komatsu, N.; Bhattacharya, S.; Shimawaki, T.; Aonuma, S.; Kimura, T.; Osuka, A. Optically active single-walled carbon nanotubes. Nat. Nanotechnol. 2007, 2, 361-365.

30. Ghosh, S.; Bachilo, S.M.; Weisman, R.B. Advanced sorting of single-walled carbon nanotubes by nonlinear density-gradient ultracentrifugation. Nat. Nanotechnol. 2010, 5, 443-450.

31. Samsonidze, G.G.; Grüneis, A.; Saito, R.; Jorio, A.; Souza Filho, A.G.; Dresselhause, G.; Dresselhause, M.S. Interband optical transitions in left- and right-handed single-walled carbon nanotubes. Phys. Rev. B 2004, 69, doi:10.1103/PhysRevB.

32. Sánchez-Castillo, A.; Román-Velázquez, C.E.; Noguez, C. Optical circular dichroism of single-wall carbon nanotubes. Phys. Rev. B 2006, 73,1-7. 
33. Moss, G.P. Basic terminology of stereochemistry. Pure Appl. Chem. 1996, 68, 2193-2222.

34. Strano, M.S. Sorting out left from right. Nat. Nanotechnol. 2007, 2, 340-341.

35. Surugau, N.; Urban, P.L. Electrophoretic methods for separation of nanoparticles. J. Sep. Sci. 2009, 32, 1889-1906.

36. Mendes, M.J.; Schmidt, H.K.; Pasquali, M. Brownian dynamics simulations of single-walled carbon nanotube separation by type using dielectrophoresis. J. Phys. Chem. B 2008, 112, 7467-7477.

37. Yamamoto, K.; Akita, S.; Nakayama, Y. Orientation of carbon nanotubes using electrophoresis. Jpn. J. Appl. Phys. 1996, 35, L917-L918.

38. Yamamoto, K.; Akita, S.; Nakayama, Y. Orientation and purification of carbon nanotubes using ac electrophoresis. J. Phys. D: Appl. Phys. 1998, 31, L34-L36.

39. Krupke, R.; Hennrich, F.; Löhneysen, H.V.; Kappes, M.M. Separation of metallic from semiconducting single-walled carbon nanotubes. Science 2003, 301, 344-347.

40. Moshammer, K.; Hennrich, F.; Kappes, M.M. Selective suspension in aqueous sodium dodecyl sulfate according to electronic structure type allows simple separation of metallic from semiconducting single-walled carbon nanotubes. Nano Res. 2009, 2, 599-606.

41. Krupke, R.; Hennrich, F.; Weber, H.B.; Kappes, M.M.; Löhneysen, H.V. Simultaneous deposition of metallic bundles of single-walled carbon nanotubes using ac-dielectrophoresis. Nano Lett. 2003, 3, 1019-1023.

42. Chen, Z.; Wu, Z.; Tong, L.; Pan, H.; Liu, Z. Simultaneous dielectrophoretic separation and assembly of single-walled carbon nanotubes on multigap nanoelectrodes and their thermal sensing properties. Anal. Chem. 2006, 78, 8069-8075.

43. Krupke, R.; Linden, S.; Rapp, M.; Hennrich, F. Thin film of metallic carbon nanotubes prepared by dielectrophoresis. Adv. Mater. 2006, 18, 1468-1470.

44. Heller, D.A.; Mayrhofer, R.M.; Baik, S.; Grinkova, Y.V.; Usrey, M.L.; Strano, M.S. Concomitant length and diameter separation of single-walled carbon nanotubes. J. Am. Chem. Soc. 2004, 126, 14567-14573.

45. O’Connell, M.; Boul, P.; Ericson, L.M.; Huffman, C.; Wang, Y.; Haroz, E.; Kuper, C.; Tour, J.; Ausman, K.D.; Smalley, R.E. Reversible water-solubilization of single-walled carbon nanotubes by polymer wrapping. Chem. Phys. Lett. 2001, 342, 265-271.

46. Doorn, S.K.; Fields, R.E.; Hu, H.; Hamon, M.A.; Haddon, R.C.; Selegue, J.P. Majidi, V. High resolution capillary electrophoresis of carbon nanotubes. J. Am. Chem. Soc. 2002, 124, 3169-3174.

47. Doorn, S.K.; Strano, M.S.; O’Connell, M.; Haroz, E.H.; Railon, K.L.; Hauge, R.H.; Smalley, R.E. Capillary electrophoresis separation of bundled and individual carbon nanotubes. J. Phys. Chem. B 2003, 107, 6063-6069.

48. Lee, D.S.; Kim, D.W.; Kim, H.S.; Lee, S.W.; Jhang, S.H.; Park, Y.W.; Campbell, E.E.B. Extraction of semiconducting cnts by repeated dielectrophoretic filtering. Appl. Phys. A 2005, 80, 5-8.

49. Peng, H.; Alvarez, N.T.; Kittrell, C.; Hauge, R.H.; Schmidt, H.K. Dielectrophoresis field flow fractionation of single-walled carbon nanotubes. J. Am. Chem. Soc. 2006, 128, 8396-8397. 
50. Baik, S.; Usrey, M.; Rotkina, L.; Strano, M.S. Using the selective functionalization of metallic single-walled carbon nanotubes to control dielectrophoretic mobility. J. Phys. Chem. B 2004, 108, 15560-15564.

51. Krupke, R.; Hennrich, F. Comment on "Using the selective functionalization of metallic single-walled carbon nanotubes to control dielectrophoretic mobility". J. Phys. Chem. B 2005, 109, 17014-17015.

52. Nair, N.; Strano, M.S. Reply to "Comment on 'Using the selective functionalization of metallic single-walled carbon nanotubes to control dielectrophoretic mobility"'. J. Phys. Chem. B 2005, 109, 17016-17018.

53. Tanaka, T.; Jin, H.; Miyata, Y.; Fujii, S.; Nishide, D.; Kataura, H. Mass separation of metallic and semiconducting single-wall carbon nanotubes using agarose gel. Phys. Stat. Sol. (b) 2009, 246, 2490-2493.

54. Tanaka, T.; Jin, H.; Miyata, Y.; Kataura, H. High-yield separation of metallic and semiconducting single-walled carbon nanotubes by agarose gel electrophoresis. Appl. Phys. Express 2008, 1, doi:10.1143/APEX.1.114001.

55. Dimaki, M.; Bøggild, P. Dielectrophoresis of carbon nanotubes using microelectrodes: A numerical study. Nanotechnology 2004, 15, 1095-1102.

56. Lee, S.W.; Lee, D.S.; Yu, H.Y.; Campbell, E.E.B.; Park, Y.W. Production of individual suspended single-walled carbon nanotubes using the ac electrophoresis technique. Appl. Phys. A 2004, 78, 283-286.

57. Krupke, R.; Hennrich, F.; Kappes, M.M.; Lóhneysen, H.V. Surface conductance induced dielectrophoresis of semiconducting single-walled carbon nanotubes. Nano Lett. 2004, 4, 1395-1399.

58. Kim, W.J.; Usrey, M.L.; Strano, M.S. Selective functionalization and free solution electrophoresis of single-walled carbon nanotubes: Separate enrichment of metallic and semiconducting swnt. Chem. Mater. 2007, 19, 1571-1576.

59. Mureau, N.; Watts, P.C.P.; Tison, Y.; Silva, S.R.P. Bulk electrical properties of single-walled carbon nanotubes immobilized by dielectrophoresis: Evidence of metallic or semiconductor behavior. Electrophoresis 2008, 29, 2266-2271.

60. Kim, Y.; Hong, S.; Jung, S.; Strano, M.S.; Choi, J.; Baik, S. Dielectrophoresis of surface conductance modulated single-walled carbon nanotubes using cationic surfactants. J. Phys. Chem. B 2006, 110, 1541-1545.

61. Lutz, T.; Donovan, K.J. Macroscopic scale separation of metallic and semiconducting nanotubes by dielectrophoresis. Carbon 2005, 43, 2508-2513.

62. Vetcher, A.A.; Srinivasan, S.; Vetcher, I.A.; Abramov, S.M.; Kozlov, M.; Baughman, R.H.; Levene, S.D. Fractionation of swnt/nucleic acid complexes by agarose gel electrophoresis. Nanotechnology 2006, 17, 4263-4269.

63. Martel, R. Sorting carbon nanotubes for electronics. ACS Nano 2008, 2, 2195-2199.

64. Arnold, M.S.; Stupp, S.I.; Hersam, M.C. Enrichment of single-walled carbon nanotubes by diameter in density gradients. Nano Lett. 2005, 5, 713-718.

65. Arnold, M.S.; Green, A.A.; Hulvat, J.F.; Stupp, S.I.; Hersam, M.C. Sorting carbon nanotubes by electronic structure using density differentiation. Nat. Nanotechnol. 2006, 1, 60-65. 
66. Stürtl, N.; Hennrich, F.; Lebedkin, S.; Kappes, M.M. Near monochiral single-walled carbon nanotube dispersions in organic solvents. J. Phys. Chem. C 2009, 113, 14628-14632.

67. Fujii, S.; Tanaka, T.; Miyata, Y.; Suga, H.; Naitoh, Y.; Minari, T.; Miyadera, T.; Tsukagoshi, K.; Kataura, H. Performance enhancement of thin-film transisters by using high-purity semiconducting single-wall carbon nanotubes. Appl. Phys. Express 2009, 2, doi:10.1143/APEX.2.071601.

68. Green, A.A.; Hersam, M.C. Colored semitransparent conductive coatings consisting of monodisperse metallic single-walled carbon nanotubes. Nano Lett. 2008, 8, 1417-1422.

69. Miyata, Y.; Yanagi, K.; Maniwa, Y.; Kataura, H. Highly stabilized conductivity of metallic single wall carbon nanotube thin films. J. Phys. Chem. C 2008, 112, 3591-3596.

70. Miyata, Y.; Yanagi, K.; Maniwa, Y.; Kataura, H. Optical evaluation of the metal-to-semiconductor ratio of single-wall carbon nanotubes. J. Phys. Chem. C 2008, 112, 13187-13191.

71. Hennrich, F.; Arnold, K.; Lebedkin, S.; Quintilla, A.; Wenzel, W.; Kappes, M.M. Diameter sorting of carbon nanotubes by gradient centrifugation: Role of endohedral water. Phys. Stat. Sol. (b) 2007, 244, 3896-3900.

72. Nair, N.; Kim, W.J.; Braatz, R.D.; Strano, M.S. Dynamics of surfactant-suspended single-walled carbon nanotubes in a centrifugal field. Langmuir 2008, 24, 1790-1795.

73. Zhu, Z.; Crochet, J.; Arnold, M.S.; Hersam, M.C.; Ulbricht, H.; Resasco, D.; Hertel, T. Pump-probe spectroscopy of exciton dynamics in $(6,5)$ carbon nanotubes. J. Phys. Chem. C 2007, 111, 3831-3835.

74. Qian, H.; Georgi, C.; Anderson, N.; Green, A.A.; Hersam, M.C.; Novotny, L.; Hartschuh, A. Exiton energy transfer in pairs of single-walled carbon nanotubes. Nano Lett. 2008, 8, 1363-1367.

75. Crochet, J.; Clemens, M.; Hertel, T. Quantum yield heterogeneities of aqueous single-walled carbon nanotube suspensins. J. Am. Chem. Soc. 2007, 129, 8058-8059.

76. Green, A.A.; Hersam, M.C. Ultracentrifugation of single-walled nanotubes. Mater. Today 2007, $10,59-60$.

77. Yanagi, K.; Miyata, Y.; Kataura, H. Optical and conductive characteristics of metallic single-wall carbon nanotubes with three basic colors; cyan, magenta, and yellow. Appl. Phys. Express 2008, 1, doi:10.1143/APEX.1.034003.

78. Sato, Y.; Yanagi, K.; Miyata, Y.; Suenaga, K.; Kataura, H.; Iijima, S. Chiral-angle distribution for separated single-walled carbon nanotubes. Nano Lett. 2008, 8, 3151-3154.

79. Niyogi, S.; Densmore, C.G.; Doorn, S.K. Electrolyte tuning of surfactant interfacial behavior for enhanced density-based separations of single-walled carbon nanotubes. J. Am. Chem. Soc. 2009, 131, 1144-1153.

80. Chernov, A.I.; Obraztsova, E.D. Metallic single-wall carbon nanotubes separated by density gradient ultracentrifugation. Phys. Stat. Sol. (b) 2009, 246, 2477-2481.

81. Yanagi, K.; Iitsuka, T.; Fujii, S.; Kataura, H. Separation of metallic and semiconducting carbon nanotubes by using sucrose as a gradient medium. J. Phys. Chem. C 2008, 112, 18889-18894. 
82. Wei, L.; Wang, B.; Goh, T.H.; Li, L.J.; Yang, Y.; Chan-Park, M.B.; Chen, Y. Selective enrichment of $(6,5)$ and $(8,3)$ single-walled carbon nanotubes via cosurfactant extraction from narrow $(n, m)$ distribution samples. J. Phys. Chem. B 2008, 112, 2771-2774.

83. Biswas, C.; Kim, K.K.; Geng, H.Z.; Park, H.K.; Lim, S.C.; Chae, S.J.; Kim, S.M.; Lee, Y.H.; Nayhouse, M.; Yum, M. Strategy for high concentration nanodispersion of single-walled carbon nanotubes with diameter selectivity. J. Phys. Chem. C 2009, 113, 10044-10051.

84. Fleurier, R.; Lauret, J.S.; Lopez, U.; Loiseau, A. Transmission electron microscopy and uv-vis-ir spectroscopy analysis of the diameter sorting of carbon nanotubes by gradient density ultracentrifugation. Adv. Funct. Mater. 2009, 19, 2219-2223.

85. Fleurier, R.; Lauret, J.S.; Flahaut, E.; Loiseau, A. Sorting and transmission electron microscopy analysis of single or double wall carbon nanotubes. Phys. Stat. Sol. (b) 2009, 246, 2675-2678.

86. Green, A.A.; Hersam, M.C. Processing and properties of highly enriched double-wall carbon nanotubes. Nat. Nanotechnol. 2009, 4, 64-70.

87. Sun, X.; Zaric, S.; Daranciang, D.; Welsher, K.; Lu, Y.; Li, X.; Dai, H. Optical properties of ultrashort semiconducting single-walled carbon nanotube capsules down to sub-10 nm. J. Am. Chem. Soc. 2008, 130, 6551-6555.

88. Fagan, J.A.; Becker, M.L.; Chun, J.; Hobbie, E.K. Length fractionation of carbon nanotubes using centrifugation. Adv. Mater. 2008, 20, 1609-1613.

89. Hennrich, F.; Lebedkin, S.; Kappes, M.M. Improving separation techniques for single-walled carbon nanotubes: Towards monodisperse samples. Phys. Stat. Sol. (b) 2008, 245, 1951-1953.

90. Fagan, J.A.; Becker, M.L.; Chun, J.; Nie, P.; Bauer, B.J.; Simpson, J.R.; Hight-Waker, A.; Hobbie, E.K. Centrifugal length separation of carbon nanotubes. Langmuir 2008, 24, 13880-13889.

91. Duesberg, G.S.; Muster, J.; Krstic, V.; Burghard, M.; Roth, S. Chromatographic size separation of single-walled carbon nanotubes. Appl. Phys. A 1998, 67, 117-119.

92. Duesberg, G.S.; Blau, W.; Byrne, H.J.; Muster, J.; Burghard, M.; Roth, S. Chromatography of carbon nanotubes. Synth. Metals 1999, 103, 2484-2485.

93. Duesberg, G.S.; Burghard, M.; Muster, J.; Philipp, G.; Roth, S. Separation of carbon nanotubes by size extrusion chromatography. Chem. Commun. 1998, 435-436.

94. Zheng, M.; Jogota, A.; Semke, E.D.; Diner, B.A.; Mclean, R.S.; Lustig, S.R.; Richardson, R.E.; Tassi, N.G. DNA-assisted dispersion and separation of carbon nanotubes. Nature Mater. 2003, 2, 338-342.

95. Zheng, M.; Jogota, A.; Strano, M.S.; Santos, A.P.; Barone, P.; Chou, S.G.; Diner, B.A.; Dresselhause, M.S.; Mclean, R.S.; Onoa, G.B.; Samsonidze, G.G.; Semke, E.D.; Usrey, M.; Walls, D.J. Structure-based carbon nanotube sorting by sequence-dependent DNA assembly. Science 2003, 302, 1545-1548.

96. Tu, X.; Manohar, S.; Jagota, A.; Zheng, M. DNA sequence motifs for structure-specific recognition and separation of carbon nanotubes. Nature 2009, 460, 250-253.

97. Liu, J.; Rinzler, A.G.; Dai, H.; Hafner, J.H.; Bradley, R.K.; Boul, P.J.; Lu, A.; Iverson, T.; Shelimov, K.; Huffman, C.B.; Rodriguez-Macias, F.; Shon, Y.S.; Lee, T.R.; Colbert, D.T.; Smalley, R.E. Fullerene pipes. Science 1998, 280, 1253-1256. 
98. Chen, B.; Selegue, J.P. Separation and characterization of singler-walled and multiwalled carbon nnoatubes by using flow field-flow fraction. Anal. Chem. 2002, 74, 4774-4780.

99. Kim, H.Y.; Choi, W.B.; Lee, N.S.; Chung, D.S.; Kang, J.H.; Han, I.T.; Kim, J.M.; Moon, M.H.; Kim, J.S. Purification and characterization of single-walled carbon nanotubes. Mater. Res. Soc. Symp. Proc. 2000, 593, 123-127.

100. Moon, M.H.; Kang, D.; Jung, J.; Kim, J. Separation of carbon nanotubes by frit inlet asymmeterical flow field-flow fractionation. J. Sep. Sci. 2004, 27, 710-717.

101. Chun, J.; Fagan, J.A.; Hobbie, E.K.; Bauer, B.J. Size separation of single-wall carbon nanotubes by flow-field flow fractionation. Anal. Chem. 2008, 80, 2514-2523.

102. Tagmatarchis, N.; Zattoni, A.; Reschiglian, P.; Prato, M. Separation and purification of functionalised water-soluble multi-walled carbon nanotubes by flow field-flow fractionation. Carbon 2005, 43, 1984-1989.

103. Tan, S.; Lopez, H.A.; Cai, C.W.; Zhang, Y. Optical trapping of single-walled carbon nanotubes. Nano Lett. 2004, 4, 1415-1419.

104. Li, X.; Tu, X.; Zaric, S.; Welsher, K.; Seo, W.S.; Zhao, W.; Dai, H. Selective synthesis combined with chemical separation of single-walled carbon nanotubes for chirality selection. J. Am. Chem. Soc. 2007, 129, 15770-15771.

105. Zheng, M.; Semke, E.D. Enrichment of single chirality carbon nanotubes. J. Am. Chem. Soc. 2007, 129, 6084-6085.

106. Zhang, L.; Tu, X.; Welsher, K.; Wang, X.; Zheng, M.; Dai, H. Optical characterization and electoric devices of nearly pure (10,5) single-walled carbon nanotubes. J. Am. Chem. Soc. 2009, 131, 2454-2455.

107. Strano, M.S.; Zheng, M.; Jagota, A.; Onoa, G.B.; Heller, D.A.; Barone, P.W.; Usrey, M.L. Understanding the nature of the DNA-assisted separation of single-walled carbon nanotubes using fluorescence and raman spectroscopy. Nano Lett. 2004, 4, 543-550.

108. Lustig, S.R.; Jagota, A.; Khripin, C.; Zheng, M. Theory of structure-based carbon nanotube separations by ion-exchange chromatography of DNA/cnt hybrids. J. Phys. Chem. B 2005, 109, 2559-2566.

109. Nair, N.; Usrey, M.; Kim, W.J.; Braatz, R.D.; Strano, M.S. Estimation of the (n, m) concentration distribution of single-walled carbon nanotubes from photoabsorption spectra. Anal. Chem. 2006, 78, 7689-7696.

110. Zheng, M.; Diner, B.A. Solution redox chemistry of carbon nanotubes. J. Am. Chem. Soc. 2004, $126,15490-15494$.

111. Zhang, L.; Zaric, S.; Tu, X.; Wang, X.; Zhao, W.; Dai, H. Assessment of chemically separated carbon nanotubes for nanoelectronics. J. Am. Chem. Soc. 2008, 130, 2686-2691.

112. Huang, X.; Mclean, R.S.; Zheng, M. High-resolution length sorting and purification of DNA-wrapped carbon nanotubes by size-exclusion chromatography. Anal. Chem. 2005, 77, 6225-6228.

113. Bauer, B.J.; Fagan, J.A.; Hobbie, E.K.; Chun, J.; Bajpai, V. Chromatographuc fractionation of swnt/DNA dispersions with on-line multi-angle light scattering. J. Phys. Chem. C 2008, 112, 1842-1850. 
114. Becker, M.L.; Fagan, J.A.; Gallant, N.D.; Bauer, B.J.; Bajpai, V.; Hobbie, E.K.; Lacerda, S.H.; Migler, K.B.; Jakupciak, J.P. Length-dependent uptake of DNA-wrapped single-walled carbon nanotubes. Adv. Mater. 2007, 19, 939-945.

115. Chattopadhyay, D.; Lastella, S.; Kim, S.; Papadimitrakopoulos, F. Length separation of zwitterion-functionalized single wall carbon nanotubes by gpc. J. Am. Chem. Soc. 2002, 124, 728-729.

116. Duesberg, G.S.; Blau, W.J.; Byrne, H.J.; Muster, J.; Burghard, M.; Roth, S. Experimental observation of individual single-wall nanotube speicies by raman microscopy. Chem. Phys. Lett. 1999, 310, 8-14.

117. Farkas, E.; Anderson, M.E.; Chen, Z.; Rinzler, A.G. Length sorting cut single wall carbon nanotubes by high performance liquid chromatography. Chem. Phys. Lett. 2002, 363, 111-116.

118. Arnold, K.; Hennrich, F.; Krupke, R.; Lebedkin, S. Kappes, M.M. Length separation studies of single-walled carbon nanotubes dispersions. Phys. Stat. Sol. (b) 2006, 243, 3073-3076.

119. Fagan, J.A.; Simpson, J.R.; Bauer, B.J.; Lacerda, S.H.D.P.; Becker, M.L.; Chun, J.; Migler, K.B.; Walker, A.R.H.; Hobbie, E.K. Length-dependent optical effects in single-wall carbon nanotubes. J. Am. Chem. Soc. 2007, 129, 10607-10612.

120. Dyke, C.A.; Stewart, M.P.; Tour, J.M. Separation of single-walled carbon nanotubes on silica gel. Materials morphology and raman excitation wavelength affect data interpretation. J. Am. Chem. Soc. 2005, 127, 4497-4509.

121. Tanaka, T.; Urabe, Y.; Nishide, D.; Kataura, H. Continuous separation of metallic and semiconducting carbon nanotubes using agarose gel. Appl. Phys. Express 2009, 2, doi: 10.1143/APEX.2.125002.

122. O’Connell, M.J.; Bachilo, S.M.; Huffman, C.B.; Moore, V.C.; Strano, M.S.; Haroz, E.H.; Rialon, K.L.; Boul, P.J.; Noon, W.H.; Kittrell, C.; Ma, J.; Hauge, R.H.; Weisman, R.B.; Smalley, R.E. Band gap fluorescence from individual single-walled carbon nanotubes. Science 2002, 297, 593-596.

123. Dyke, C.A.; Tour, J.M. Covalent functionalization of single-walled carbon nanotubes for materials applications. J. Phys. Chem. A 2004, 108, 11151-11159.

124. Chattopadhyay, D.; Galeska, I.; Papadimitrakopoulos, F. A route for bulk separation of semiconducting from metallic single-wall carbon nanotubes. J. Am. Chem. Soc. 2003, 125, 3370-3375.

125. Ju, S.Y.; Ulz, M.; Papadimitrakopoulos, F. Enrichment mechanism of semiconducting single-walled carbon nanotubes by surfactant amines. J. Am. Chem. Soc. 2009, 131, 6775-6784.

126. Samsonidze, G.G.; Chou, S.G.; Santos, A.P.; Brar, V.W.; Dresselhaus, G.; Dresselhaus, M.S.; Selbst, A.; Swan, A.K.; Ünuü, M.S.; Goldberg, B.B.; Chattopadhyay, D.; Kim, S.N.; Papadimitrakopoulos, F. Quatitative evaluation of the octadecylamine-assisted bulk separation of semiconducting and metallic single-wall carbon nanotubes by resonance raman spectroscopy. Appl. Phys. Lett. 2004, 85, 1006-1008.

127. Kim, S.N.; Luo, Z.; Papadimitrakopoulos, F. Diameter and metallicity dependent redox influences on the separation of single-wall carbon nanotubes. Nano Lett. 2005, 5, 2500-2504.

128. Maeda, Y.; Kimura, S.; Kanda, M.; Hirashima, Y.; Hasegawa, T.; Wakahara, T.; Lian, Y.; Nakahodo, T.; Tsuchiya, T.; Akasaka, T.; Lu, J.; Zhang, X.; Gao, Z.; Yu, Y.; Nagase, S.; 
Kazaoui, S.; Minami, N.; Shimizu, T.; Tokumoto, H.; Saito, R. Large-scale separation of metallic and semiconducting single-walled carbon nanotubes. J. Am. Chem. Soc. 2005, 127, 10287-10290.

129. Maeda, Y.; Kanda, M.; Hirashima, Y.; Hasegawa, T.; Kimura, S.; Lian, Y.; Wakahara, T.; Akasaka, T.; Kazaoui, S.; Minami, N.; Okazaki, T.; Hayamizu, Y.; Hata, K.; Lu, J.; Nagase, S. Dispersion and separation of small-diameter single-walled carbon nanotubes. J. Am. Chem. Soc. 2006, 128, 12239-12242.

130. Lu, J.; Lai, L.; Luo, G.F.; Zhou, J.; Qin, R.; Wang, D.; Wang, L.; Mei, W. N.; Li, G.; Gao, Z.; Nagase, S.; Maeda, Y.; Akasaka, T.; Yu, D. Why semiconducting single-walled carbon nanotubes are separated from their metallic counterparts. Small 2007, 3, 1566-1576.

131. Chen, F.; Wang, B.; Chen, Y.; Li, L.J. Toward the extraction of single species of single-walled carbon nanotubes using fluorene-based polymers. Nano Lett. 2007, 7, 3013-3017.

132. Nish, A.; Hwang, J.Y.; Doig, J.; Nicholas, R.J. Highly selective dispersion of single-walled carbon nanotubes using aromatic polymers. Nat. Nanotechnol. 2007, 2, 640-646.

133. Hwang, J.Y.; Nish, A.; Doig, J.; Douven, S.; Chen, C.W.; Chen, L.C.; Nicholas, R.J. Polymer structure and solvent effects on the selective dispersion of single-walled carbon nanotubes. J. Am. Chem. Soc. 2008, 130, 3543-3553.

134. Dalton, A.B.; Stephan, C.; Coleman, J.N.; McCarthy, B.; Ajayan, P.M.; Lefrant, S.; Bernier, P.; Blau, W.J.; Byrne, H.J. Selective interaction of a semiconjugated organic polymer with single-wall nanotubes. J. Phys. Chem. B 2000, 104, 10012-10016.

135. Gregan, E.; Keogh, S.M.; Maguire, A.; Hedderman, T.G.; Neill, L.O.; Chambers, G.; Byrne, H.J. Purification and isolation of swnts. Carbon 2004, 42, 1031-1035.

136. Keogh, S.M.; Hedderman, T.G.; Lynch, P.; Farrell, G.F.; Byrne, H.J. Bundling and diameter selectivity in hipco swnts poly(p-phenylenevinylene-co-2,5-dioctyloxy-m-phenylene) composites. J. Phys. Chem. B 2006, 110, 19369-19374.

137. Keogh, S.M.; Hedderman, T.G.; Gregan, E.; Farrell, G.; Chambers, G.; Byrne, H.J. Spectroscopic analysis of single-walled carbon nanotubes and semiconjugated polymer composites. J. Phys. Chem. B 2004, 108, 6233-6241.

138. Yi, W.; Malkovskiy, A.; Chu, Q.; Sokolov, A.P.; Colon, M.L.; Meador, M.; Pang, Y. Wrapping of single-walled carbon nanotubes by a $\pi$-conjugated polymer: The role of polymer conformation-controlled size selectivity. J. Phys. Chem. B 2008, 112, 12263-12269.

139. Sanchez-Castillo, A.; Noguez, C. Understanding optical activity in single-walled carbon nanotubes from first-principles studies. J. Phys. Chem. C 2010, 114, 9640-9644.

140. Tanaka, T.; Jin, H.; Miyata, Y.; Fujii, S.; Suga, H.; Naitoh, Y.; Minari, T.; Miyadera, T.; Tsukagoshi, K.; Kataura, H. Simple and scalable gel-based separation of metallic and semiconducting acrbon nanotubes. Nano Lett. 2009, 9, 1497-1500.

141. LeMieux, M.C.; Roberts, M.; Barman, S.; Jin, Y.W.; Kim, J.M.; Bao, Z. Self-sorted, aligned nanotube networks for thin-film transistors. Science 2008, 321, 101-104.

142. Chen, Z.; Du, X.; Du, M.H.; Rancken, C.D.; Cheng, H.P.; Rinzler, A.G. Bulk separation enrichment in metallic or semiconducting single-walled carbon nanotubes. Nano Lett. 2003, 3, 1245-1249. 
143. Park, N.; Miyamoto, Y.; Lee, K.; Choi, W.I.; Ihm, J.; Yu, J. Han, S. Band gap sensitivity of bromine adsorption at carbon nanotubes. Chem. Phys. Lett. 2005, 403, 135-139.

144. Li, H.; Zhou, B.; Lin, Y.; Gu, L.; Wang, W.; Fernando, K.A.S.; Kumar, S.; Allard, L.F.; Sun, Y.P. Selective interactions of porphyrins with semiconducting single-walled carbon nanotubes. J. Am. Chem. Soc. 2004, 126, 1014-1015.

145. Wang, W.; Fernando, K.A.S.; Lin, Y.; Meziani, M.J.; Veca, L.M.; Cao, L.; Zhang, P.; Kimani, M.M.; Sun, Y.P. Metallic single-walled carbon nanotubes for conductive nanocomposites. J. Am. Chem. Soc. 2008, 130, 1415-1419.

146. Ju, S.Y.; Doll, J.; Sharma, I.; Papadimitrakopoulos, F. Seletion of carbon nanotubes with specific chiralities using helical assemblies of flavin mononucleotide. Nat. Nanotechnol. 2008, 3, 356-362.

147. Ogunro, O.O.; Wang, X.Q. Quantum electronic stability in selective enrichment of carbon nanotubes. Nano Lett. 2009, 9, 1034-1038.

148. Marquis, R.; Greco, C.; Sadokierska, I.; Lebedkin, S.; Kappes, M.M.; Michel, T.; Alvarez, L.; Sauvajol, J.L.; Meunier, S.; Mioskowski, C. Supramolecular discrimination of carbon nanotubes according to their helicity. Nano Lett. 2008, 8, 1830-1835.

149. Marquis, R.; Kulikiewicz, K.; Lebedkin, S.; Kappes, M.M.; Mioskowski, C.; Meunier, S.; Wagner, A. Axially chiral facial amphiphiles with a dihydronaphthopentaphene structure as molecular tweezers for swnts. Chem. Eur. J 2009, 15, 11187-11196.

150. Ortis-Acevedo, A.; Xie, H.; Zorbas, V.; Sampson, W.M.; Dalton, A.B.; Baughman, R.H.; Draper, R.K.; Musselman, I.H.; Dieckmann, G.R. Diameter-selective solubilization of single-walled carbon nanotubes by reversible cyclic peptides. J. Am. Chem. Soc. 2005, 127, 9512-9517.

151. Becraft, E.J.; Klimenko, A.S.; Dieckmann, G.R. Influence of alternating 1-/d-amino acid chiralities and disulfide bond geometry on the capacity of cysteine-containing reversible cyclic peptides to disperse carbon nanotubes. Pept. Science 2009, 92, 212-221.

152. Dodziuk, H.; Ejchart, A.; Anczewski, W.; Ueda, H.; Krinichnaya, E.; Dolgonos, G.; Kutner, W. Water solubilization, determination of the number of different types of single-walled carbon nanotubes and their partial separation with respect to diameters by complexation with eta-cyclodextrin. Chem. Commun. 2003, 986-987.

153. Tromp, R.M.; Afzali, A.; Freitag, M.; Mitzi, D.B.; Chen, Z. Novel strategy for diameter-selective separation and functionalization of single-walled carbon nanotubes. Nano Lett. 2008, 8, 469-472.

154. Voggu, R.; Rao, K.V.; George, S.J.; Rao, C.N.R. A simple method of separating metallic and semiconducting single-walled carbon nanotubes based on molecular charge transfer. J. Am. Chem. Soc. 2010, 10.1021/jp100190p.

155. Yang, H.; Wang, S.C.; Mercier, P.; Akins, D.L. Diameter-selective dispersion of single-walled carbon nanotubes using a water-soluble, biocompatible polymer. Chem. Commun. 2006, 1425-1427.

156. Saito, K.; Troiani, V.; Qiu, H.; Solladie, N.; Sakata, T.; Mori, H.; Ohama, M.; Fukuzumi, S. Nondestructive formation of supramolecular nanohybrids of single-walled carbon nanotubes with flexible porphyrinic polypeptides. J. Phys. Chem. C 2007, 111, 1194-1199. 
157. Chaturvedi, H.; Giordano, A.N.; Kim, M.J.; MacDonnell, F.M.; Subaran, S.S.; Poler, J.C.; "Mechanically docked" Metallodendrimers about single-walled carbon nanotubes. J. Phys. Chem. C 2009, 113, 11254-11261.

158. Fernando, K.A.S.; Lin, Y.; Wang, W.; Cao, L.; Meziani, M. J.; Wang, X.; Veca, L.M.; Zhang, P.; Quinn, R.A.; Allard, L.F.; Sun, Y.P. Diameter-selective fractionation of hipco single-walled carbon nanotubes in repeated functionalization reactions. J. Phys. Chem. C 2007, 111, 10254-10259.

159. Huang, W.; Fernando, K.A.S.; Lin, Y.; Zhou, B.; Allard, L.F.; Sun, Y.P. Preferential solubilization of smaller single-walled carbon nanotubes in sequential functionalization reactions. Langmuir 2003, 19, 7084-7088.

160. Ziegler, K.J.; Schmidt, D.J.; Rauwald, U.; Shah, K.N.; Flor, E.L.; Hauge, R.H.; Smalley, R.E. Length-dependent extraction of single-walled carbon nanotubes. Nano Lett. 2005, 5, 2355-2359.

161. Yan, L.Y.; Li, W.; Fan, X.F.; Wei, L.; Chen, Y.; Kuo, J.L.; Li, L.J.; Kwak, S.K.; Mu, Y.; Chan-Park, M.B. Enrichment of $(8,4)$ single-walled carbon nanotubes through coextraction with heparin. Small 2010, 6, 110-118.

162. Fantini, C.; Jorio, A.; Santos, A.P.; Peressinotto, V.S.T.; Pimenta, M.A. Characterization of DNA-wrapped carbon nanotubes by resonance raman and optical absorption spectroscopies. Chem. Phys. Lett. 2007, 439, 138-142.

163. Tomonari, Y.; Murakami, H.; Nakashima, N. Solubilization of single-waleed carbon nanotubes by using polycyclic aromatic ammonium amphiphiles in water-strategy for the design of high-performance solubilizers. Chem. Eur. J. 2006, 12, 4027-4034.

164. Backes, C.; Mundloch, U.; Ebel, A.; Hauke, F.; Hirsch, A. Dispersion of hipco and comocat single-walled nanotubes (swnts) by water soluble pyrene derivatives-depletion of small diameter swnts. Chem. Eur. J 2010, 16, 3314-3317.

165. MacDonald, T.J.; Engtrakul, C.; Jones, M.; Rumbles, G.; Heben, M.J. Kinetics of pl quenching during single-waleed carbon nanotubes rebundling and diameter-dependent surfactant interactions. J. Phys. Chem. B 2006, 110, 25339-25346.

166. Ramesh, S.; Shan, H.; Haroz, E.; Billups, W.E.; Hauge, R.; Adams, W.W.; Smalley, R.E. Diameter selection of single-walled carbon nanotubes through programmable solvation in binary sulfonic acid mixtures. J. Phys. Chem. C 2007, 111, 17827-17834.

167. Joselevich, E. Electronic structure and chemical reactivity of carbon nanotubes: A chemist's view. Chem. Phys. Chem. 2004, 5, 619-624.

168. Miyata, Y.; Maniwa, Y.; Kataura, H. Selective oxidation of semiconducting single-wall carbon nanotubes by hydrogen peroxide. J. Phys. Chem. B 2006, 110, 25-29.

169. Miyata, Y.; Kawai, T.; Miyamoto, Y.; Yanagi, K.; Maniwa, Y.; Kataura, H. Chirality-dependent combustion of single-walled carbon nanotubes. J. Phys. Chem. C 2007, 111, 9671-9677.

170. Yudasaka, M.; Zhang, M.; Iijima, S. Diameter-selective removal of single-wall carbon nanotubes through light-assisted oxidation. Chem. Phys. Lett. 2003, 374, 132-136.

171. McDonald, T.J.; Blackburn, J.L.; Metzger, W.K.; Rumbles, G.; Heben, M.J. Chiral-selective protection of single-walled carbon nanotube photoluminescence by surfactant selection. J. Phys. Chem. C 2007, 111, 17894-17900. 
172. Zhang, M.; Yudasaka, M.; Miyauchi, Y.; Maruyama, S.; Iijima, S. Changes in the fluorescence spectrum of indivisual single-wall carbon nanotubes induced by light-assisted oxidation with hydroperoxide. J. Phys. Chem. B 2006, 110, 8935-8940.

173. Banerjee, S.; Wong, S.S. Selective metallic tube reactivity in the solution-phase osmylation of single-walled carbon nanotubes. J. Am. Chem. Soc. 2004, 126, 2073-2081.

174. Qui, H.; Maeda, Y.; Akasaka, T. Facile and scalable route for highly efficient enrichment of semiconducting single-walled carbon nanotubes. J. Am. Chem. Soc. 2009, 131, 16529-16533.

175. Yang, C.M.; Park, J.S.; An, K.H.; Lim, S.C.; Seo, K.; Kim, B.; Park, K.A.; Han, S.; Park, C.Y.; Lee, Y.H. Selective removal of metallic single-walled carbon nanotubes with small diameters by using nitric and sulfuric acids. J. Phys. Chem. B 2005, 109, 19242-19248.

176. Menna, E.; Negra, F.D.; Fontana, M.D. Selectivity of chemical oxidation attack of single-wall carbon nanotubes in solution. Phys. Rev. B 2003, 68, doi:10.1103/PhysRevB.68.193412.

177. Wiltshire, J.G.; Khlobystov, A.N.; Li, L.J.; Lyapin, S.G.; Briggs, G.A.D.; Nicholas, R.J. Comparative studies on acid and thermal based selective purification of hipco produced single-walled carbon nanotubes. Chem. Phys. Lett. 2004, 386, 239-243.

178. Bergeret, C.; Cousseau, J.; Fernandez, V.; Mevellec, J.Y.; Lefrant, S. Spectroacopic evidence of carbon nanotubes' metallic character loss induced by covalent functionalization via nitric acid purification. J. Phys. Chem. C 2008, 112, 16411-16416.

179. Banerjee, S.; Wong, S.S. Demonstration of diameter-selective reactivity in the sidewall ozonation of swnts by resonance raman spectroscopy. Nano Lett. 2004, 4, 1445-1450.

180. Banerjee, S.; Wong, S.S. Rational sidewall functionalization and purification of single-walled carbon nanotubes by solution-phase ozonolysis. J. Phys. Chem. B 2002, 106, 12144-12151.

181. Kato, Y.; Niidome, Y.; Nakashima, N. Efficient separation of (6,5) single-walled carbon nanotubes using a "Nanometal sinker". Angew. Chem. Int. Ed. 2009, 48, 5435-5438.

182. Yoon, S.M.; Kim, S.J.; Shin, H.J.; Benayad, A.; Choi, S.J.; Kim, K.K.; Kim, S.M.; Park, Y.J.; Kim, G.; Choi, J.Y.; Lee, Y.H. Selective oxidation on metallic carbon nanotubes by halogen oxoanions. J. Am. Chem. Soc. 2008, 130, 2610-2616.

183. Nagasawa, S.; Yudasaka, M.; Hirahara, K.; Ichihashi, T.; Iijima, S. Effect of oxidation on single-wall carbon nanotubes. Chem. Phys. Lett. 2000, 328, 374-380.

184. Zhou, W.; Ooi, Y.H.; Russo, R.; Papanek, P.; Luzzi, D.E.; Fischer, J.E.; Bronikowski, M.J.; Willis, P.A.; Smalley, R.E. Structural characterization and diameter-dependent oxidative stability of single wall carbon nanotubes synthesized by the catalytic decomposition of co. Chem. Phys. Lett. 2001, 350, 6-14.

185. An, K.H.; Park, J.S.; Yang, C.M.; Jeong, S.Y.; Lim, S.C.; Kang, C.; Son, J.H.; Jeong, M.S.; Lee, Y.H. A diameter-selective attack of metallic carbon nanotubes by nitronium ions. J. Am. Chem. Soc. 2005, 127, 5196-5203.

186. An, K.H.; Yang, C.M.; Lee, J.Y.; Lim, S.C.; Kang, C.; Son, J.H.; Jeong, M.S.; Lee, Y.H. A diameter-selective chiral separation of single-wall carbon nanotubes using nitronium ions. J. Electronic Mater. 2006, 35, 235-242.

187. Seo, K.; Park, K.A.; Kim, C.; Han, S.; Kim, B.; Lee, Y.H. Chirality- and diameter-dependent reactivity of NO2 on carbon nanotube walls. J. Am. Chem. Soc. 2005, 127, 15724-15729. 
188. Hu, H.; Zhao, B.; Hamon, M.A.; Kamaras, K.; Itkis, M.E.; Haddon, R.C. Sidewall functionalization of single-walled carbon nanotubes by addition of dichlorocarbene. J. Am. Chem. Soc. 2003, 125, 14893-14900.

189. Kamaras, K.; Itkis, M.E.; Hu, H.; Zhao, B.; Haddon, R.C. Covalent bond formation to a carbon nanotube metal. Science 2003, 301, 1501.

190. Strano, M.S.; Dyke, C.A.; Usrey, M.L.; Barone, P.W.; Allen, M.J.; Shan, H.; Kittrell, C.; Hauge, R.H.; Tour, J.M.; Smalley, R.E. Electronic structure control of single-walled carbon nanotube functionalization. Science 2003, 301, 1519-1522.

191. Ghosh, S.; Rao, C.N.R. Separation of metallic and semiconducting single-walled carbon nanotubes through fluorous chemistry. Nano Res. 2009, 2, 183-191.

192. Balasubramanian, K.; Sordan, R.; Burghard, M.; Kern, K. A selective electrochemical approach to carbon nanotube field-effect transistes. Nano Lett. 2004, 4, 827-830.

193. An, L.; Fu, Q.; Lu, C.; Liu, J. A simple chemical route to selectively eliminate metallic carbon nanotubes in nanotube network devices. J. Am. Chem. Soc. 2004, 126, 10520-10521.

194. Strano, M.S. Probing chiral selective reactions using a revised kataura plot for the interpretation of single-walled carbon nanotube spectroscopy. J. Am. Chem. Soc. 2003, 125, 16148-16153.

195. Balasubramanian, K.; Friedrich, M.; Jiang, C.; Fan, Y.; Mews, A.; Burghard, M.; Kern, K. Electrical transport and confocal raman studies of electrochemically modified individual carbon nanotubes. Adv. Mater. 2003, 15, 1515-1518.

196. Toyoda, S.; Yamaguchi, Y.; Hiwatashi, M.; Tomonari, Y.; Murakami, H.; Nakashima, N. Separation of semiconducting single-walled carbon nanotubes by using a long-alkyl-chain benzenediazonium compound. Chem. Asian J. 2007, 2, 145-149.

197. Usrey, M.L.; Lippmann, E.S.; Strano, M.S. Evidence for a two-step mechanism in electronically selective single-walled carbon nanotube reactions. J. Am. Chem. Soc. 2005, 127, 16129-16135.

198. Doyle, C.D.; Rocha, J.D.R.; Weisman, R.B.; Tour, J.M. Structure-dependent reactivity of semiconducting single-walled carbon nanotubes with benzenediazonium salts. J. Am. Chem. Soc. 2008, 130, 6795-6800.

199. Sumpter, B.G.; Jiang, D.E.; Meunier, V. New insight into cqrbon nanotube electronic-structure selectivity. Small 2008, 4, 2035-2042.

200. Wang, C.; Cao, Q.; Ozel, T.; Gaur, A.; Rogers, J.A.; Shim, M. Electronically selective chemical functionalization of carbon nanotubes: Correlation between raman spectral and electrical responses. J. Am. Chem. Soc. 2005, 127, 11460-11468.

201. Nair, N.; Kim, W.J.; Usrey, M.L.; Strano, M.S. A structure-reactivity relationship for single walled carbon nanotubes reacting with 4-hydroxybenzene diazonium salt. J. Am. Chem. Soc. 2007, 129, 3946-3954.

202. Fantini, C.; Usrey, M.; Strano, M.S. Investigation of electronic and vibrational properties of single-walled carbon nanotubes functionalized with diazonium salts. J. Phys. Chem. C 2007, $111,17941-17946$.

203. Yang, C.M.; An, K.H.; Park, J.S.; Park, K.A.; Lim, S.C.; Cho, S.H.; Lee, Y.S.; Park, W.; Park, C.Y.; Lee, Y.H. Preferential etching of metallic single-walled carbon nanotubes with small diameter by fluorine gas. Phys. Rev. B 2006, 73, doi: 10.1103/PhysRevB.73.075419. 
204. Lee, Y.; Jeon, K.S.; Lim, H.; Shin, H.S.; Jin, S.M.; Byon, H.R.; Suh, Y.D.; Choi, H.C. Silencing of metallic single-walled carbon nanotubes via spontaneous hydrosilylation. Small 2009, 5, 1398-1402.

205. Kanungo, M.; Lu, H.; Malliaras, G.G.; Blanchet, G.B. Suppression of metallic conductivity of single-walled carbon nanotubes by cycloaddition reactions. Science 2009, 323, 234-237.

206. Zhang, H.; Liu, Y.; Cao, L.; Wei, D.; Wang, Y.; Kajiura, H.; Li, Y.; Noda, K.; Luo, G.; Wang, L.; Zhou, J.; Lu, J.; Gao, Z. A facile low-cost, and scalable method of selective ething of semiconducting single-walled carbon nanotubes by a gas reaction. Adv. Mater. 2009, 21, 813-816.

207. Wunderlich, D.; Hauke, F.; Hirsch, A. Preferred functionalization of metallic and small-diameter single-walled carbon nanotubes by nucleophilic addition of organolithium and magnesium compounds followed by reoxidation. Chem. Eur. J. 2008, 14, 1607-1614.

208. M.-Moyon, C.; Izard, N.; Doris, E.; Mioskowski, C. Separation of semiconducting from metallic carbon nanotubes by selective functionalization with azomethine ylide. J. Am. Chem. Soc. 2006, 128, 6552-6553.

209. Collins, P.G.; Arnold, M.S.; Avouris, P. Engineering carbon nanotubes and nanotube circuits using electrical breakdown. Science 2001, 292, 706-709.

210. Collins, P.G.; Hersam, M.C.; Arnold, M.S.; Martel, R.; Avouris, P. Current saturation and electrical breakdown in multiwalled carbon nanotubes. Phys. Rev. Lett. 2001, 86, 3128-3131.

211. Zhou, Y.; Gaur, A.; Hur, S.H.; Kocabas, C.; Meitl, M.A.; Shim, M.; Rogers, J.A. P-channel, $\mathrm{n}$-channel thin film transisters and p-n diodes based on single wall carbon nanotube networks. Nano Lett. 2004, 4, 2031-2035.

212. Zhang, G.; Qi, P.; Wang, X.; Lu, Y.; Li, X.; Tu, R.; Bangsaruntip, S.; Mann, D.; Zhang, L.; Dai, H. Selective ething of metallic carbon nanotubes by gas-phase reaction. Science 2006, 314, 974-977.

213. Hassanien, A.; Tokumoto, M.; Umek, P.; Vrbanic, D.; Mozetic, M.; Mihailovic, D.; Venturini, P.; Pejovnik, S. Selective etching of metallic single-wall carbon nanotubes with hydrogen plasma. Nanotechnology 2005, 16, 278-281.

214. Maehashi, K.; Ohno, Y.; Inoue, K.; Matsumoto, K. Chirality selection of single-walled carbon nanotubes by laser resonance chirality selection method. Appl. Phys. Lett. 2004, 85, 858-860.

215. Huang, H.; Maruyama, R.; Noda, K.; Kajiura, H.; Kadono, K. Preferential destruction of metallic single-walled carbon nanotubes by laser irradiation. J. Phys. Chem. B 2006, 110, 7316-7320.

216. Song, J.W.; Seo, H.W.; Park, J.K.; Kim, J.E.; Choi, D.G.; Han, C.S. Selective removal of metallic swnts using microwave radiation. Curr. Appl. Phys. 2008, 8, 725-728.

217. Priya, B.R.; Byrne, H.J. Quantitative analyses of microwave-treated hipco carbon nanotubes using absorption and raman spectroscopy. J. Phys. Chem. C 2009, 113, 7134-7138.

218. Zhang, Y.; Zhang, Y.; Xian, X.; Zhang, J.; Liu, Z. Sorting out semiconducting single-walled carbon nanotube arrays by preferential destruction of metallic tubes using xenon-lamp irradiation J. Phys. Chem. C 2008, 112, 3849-3856.

219. Kalbác, M.; Kavan, L.; Dunsch, L. Selective ething of thin single-walled carbon nanotubes. J. Am. Chem. Soc. 2009, 131, 4529-4534. 
220. Niyogi, S.; Boukhalfa, S.; Chikkannanavar, S.B.; McDonald, T.J.; Heben, M.J.; Doorn, S.K. Selective aggregation of single-walled carbon nanotubes via salt addition. J. Am. Chem. Soc. 2007, 129, 1898-1899.

221. Kavan, L.; Dunsch, L. Diameter-selective electrochemical doping of hipco single-walled carbon nanotubes. Nano Lett. 2003, 3, 969-972.

222. Shim, H.J.; Kim, S.M.; Yoon, S.M.; Benayad, A.; Kim, K.K.; Kim, S.J.; Park, H.K.; Choi, J.Y.; Lee, Y.H. Tailoring electronic structures of carbon nanotubes by solvent with electron-donating and -withdrawing groups. J. Am. Chem. Soc. 2008, 130, 2062-2066.

223. O'Connell, M.; Eibergen, E.E.; Doorn, S.K. Chiral selectivity in the charge-transfer bleaching of single-walled carbon naotube spectra. Nature Mater. 2005, 4, 412-418.

224. Lu, J.; Nagase, S.; Zhang, X.; Wang, D.; Ni, M.; Maeda, Y.; Wakahara, T.; Nakahodo, T.; Tsuchiya, T.; Akasaka, T.; Gao, Z.; Yu, D.; Ye, H.; Mei, W.N.; Zhou, Y. Selective interaction of large or charge-transfer aromatic molecules with metallic single-walled carbon nanotubes: Critical role of the molecular size and orientation. J. Am. Chem. Soc. 2006, 128, 5114-5118.

225. Bonard, J.M.; Stora, T.; Salvetat, J.P.; Maier, F.; Stöckli, T.; Duschl, C.; Forró, L.; Heer, W.A.D.; Chatelain, A. Purification and size-selection of carbon nanotubes. Adv. Mater. 1997, 9 , 827-831.

226. Bandow, S.; Rao, A.M.; Williams, K.A.; Thess, A.; Smalley, R.E.; Eklund, P.C. Purification of single-wall carbon nanotubes by microfilteration. J. Phys. Chem. B 1997, 101, 8839-8842.

227. Bachilo, S.M.; Strano, M.S.; Kittrell, C.; Hauge, R.H.; Smalley, R.E.; Weisman, R.B. Structure-assigned optical spectra of single-walled carbon nanotubes. Science 2002, 298, 2361-2366.

(C) 2010 by the authors; licensee MDPI, Basel, Switzerland. This article is an Open Access article distributed under the terms and conditions of the Creative Commons Attribution license (http://creativecommons.org/licenses/by/3.0/). 